\title{
Assessment of heavy metals contamination and associated risks in shallow groundwater sources from three different residential areas within Ibadan metropolis, southwest Nigeria
}

\author{
Saheed Adekunle Ganiyu ${ }^{1} \cdot$ Abimbola Temitope Oyadeyi $^{1} \cdot$ Azeem Adedeji Adeyemi $^{2}$
}

Received: 9 December 2020 / Accepted: 19 April 2021 / Published online: 24 April 2021

(c) The Author(s) 2021

\begin{abstract}
This study has been conducted to appraise the concentrations of selected heavy metals and total dissolved solids (TDSs) in the drinking water from shallow wells in parts of Ibadan metropolis, southwest Nigeria. Fifteen (15) water samples were collected from three representative residential locations [traditional core area (TCA), peri-urban area (PUA), and urban area (UA)] for geochemical analysis. Heavy metals and TDS were analyzed with the aid of atomic absorption spectrophotometer and calibrated meter, respectively. The mean concentration $(\mathrm{mg} / \mathrm{L})$ of $\mathrm{Zn}, \mathrm{Pb} \mathrm{Mn}, \mathrm{Fe}$, and $\mathrm{Cd}$ has been 3.930, 0.658, 0.0304, 1.698 , and 0.501, respectively, and as a consequence, the order of abundance of studied metals was $\mathrm{Zn}>\mathrm{Fe}>\mathrm{Pb}>\mathrm{Cd}>\mathrm{Mn}$. Concentrations of $\mathrm{Zn}, \mathrm{Fe}, \mathrm{Pb}$, and $\mathrm{Cd}$ were higher than recommended standards in $60 \%, 86.7 \%, 100 \%$, and $100 \%$ of groundwater samples, respectively. However, at all points tested, the mean concentrations of Mn and TDS in water samples lie within the safe limits set by World Health Organization. The evaluation of geoaccumulation index $\left(I_{\text {geo }}\right)$, enrichment factor $(\mathrm{EF})$, and contamination factor suggests that representative water samples were low-to-moderate contamination. The potential ecological risk index advocates low-to-moderate ecological risk in TCA and PUA, while it demonstrated exclusive "moderate" risk in UA. Further, the range of pollution load index (PLI) $(0.55-1.32)$ in both TCA and PUA shows nil-to-moderate pollution status, while PLI values $>1$ in UA indicate moderate contaminated state. The degree of contamination in groundwater showed the following trends: UA $>$ TCA $>$ PUA in the study area. Moreover, the results of EF and quantification of contamination of analyzed metals in water samples indicate geogenic and anthropogenic inputs. The contribution of studied metals to the incidence of non-cancer risk via oral intake within the residential sites follows the order: cadmium $>$ lead $>$ zinc $>$ iron $>$ manganese. The hazard index as a result of ingested heavy metals for the three population classes surpasses the acceptable range in the order of infant < child < adult. Cadmium and lead made considerable impact to the estimation of cancer risk in the study area for the three human population categories. Factor analysis extracted only one component that explained $94.64 \%$ of the entire variance, while cluster analysis identified three distinct groups based on similar water quality characteristics. Based on the findings of the study, awareness programs toward protecting the shallow groundwater sources should be launched, encouraged, and sustained. Moreover, the study suggests better hygienic practices and pre-treatment of contaminated water before consumption.
\end{abstract}

Keywords Heavy metals $\cdot$ Groundwater $\cdot$ Ibadan metropolis $\cdot$ Health and ecological risks $\cdot$ Residential areas

Saheed Adekunle Ganiyu

adekunsa@yahoo.com

1 Department of Physics, Federal University of Agriculture, Abeokuta, Ogun State, Nigeria

2 Department of Environmental Management and Toxicology, Federal University of Agriculture, Abeokuta, Ogun State, Nigeria

\section{Introduction}

Water is an indispensable natural resource used on a daily basis for various purposes. Humans use water from various sources for a variety of daily activities, including household, agricultural, and manufacturing uses. However, each of the aforesaid uses has its own unique water quality categorization that determines its fittingness. Groundwater serves as a major source of water resources and readily available in many countries (Prasad and Kumar 2008; Amadi et al. 2013; 
Selvakumar et al. 2017). Subsurface water is the main supply of drinking water in most third world countries (Lutterodt et al. 2018). According to Kim and Park (2016), groundwater is used for drinking purpose by more than $20 \%$ of the world population. The alternative to s groundwater, i.e., surface water, that can supplement insufficient quantity of water from hand-dug wells and boreholes, is not voluntarily present everywhere and, more importantly, is more easily contaminated than groundwater sources (Sorensen et al. 2015; Mbaka et al. 2017; Mazhar et al. 2019). However, unhygienic practices such as washing of clothes, dumping of animal wastes, and open defecation around groundwater sources also pose as threats to groundwater sources and contribute significantly to the decline in potable water (Mbaka et al. 2017). The need to guard diligently the available groundwater resources is therefore of utmost priority to environmental scientists and policy makers as quality of water is as important as its available quantity (Singh and Singh 2018). Contaminants in various forms can come in contact with the water body through natural and various anthropogenic sources, reduce the amount of potable water to the populace, and likely rise in health risks linked with the use of polluted water.

Metals are an inextricable part of the earth's crust, but their levels in water and porous media such as soil and sediment are a major source of worry for conservationists due to their dangerous, non-biodegradable, and long-lasting properties (Chen et al. 2017; Giri and Singh 2019; Shah et al. 2019; Kumar et al. 2020a,b). Heavy metals (HMs) are group of metals and metalloids characterized by specific gravities greater than 5 and atomic densities larger than $4 \mathrm{~g} /$ cm3 (Barzegar et al. 2015; Ganiyu et al. 2017; Enuneku et al. 2018; Kumar et al. 2020c). HMs can be found in water from geological or manmade activities (Nawab et al. 2017; Paul et al. 2019).

Toxicity of HMs can be introduced into the body through inhalation, dermal contact, and ingestion (Olujimi et al. 2014; Ayedun et al. 2015; Ogundele et al. 2019; Kumar et al. 2020b). It should be noted that only a small number of HMs (in very small quantities) are considered important for different biochemical reactions in the human body (Singh et al. 2011; Selvam et al. 2017; Shankar 2019; Kumar et al. 2020a, $\mathrm{b}, \mathrm{c})$. Because of their long biological half lives, the majority of heavy metals such as $\mathrm{Cd}, \mathrm{As}, \mathrm{Pb}, \mathrm{Mn}, \mathrm{Fe}, \mathrm{Cr}$, and $\mathrm{Hg}$ pose a significant threat to the normal performance of human body tissues, resulting in various diseases (Suvarapu and Baek 2017; Barzegar et al. 2019; Kumar et al. 2020a,b,c). For instance, lead $(\mathrm{Pb})$ is reported to be the second most toxic metal after arsenic (As) and comprises $0.002 \%$ of earth's crust (Arias et al. 2010; Kumar et al. 2020a). The contamination of groundwater with arsenic in certain geographical locations can occur either through geogenic or through anthropogenic inputs (Pal et al. 2020; Kumar et al.
2021). Large number of peoples residing in different countries is reported to be exposed to increased intake of arsenic-rich groundwater (Ravindra and Mor 2019; Kumar et al. 2021). The existence of dissolved metals beyond permissible values in drinking water may lead to damaging risks to residents where enormous farming and metal-induced human activities are taken place (Wu et al. 2019; Kumar et al. 2021). It has been reported that persons respond comparatively fast to air and water contamination; therefore, it is necessity to evaluate concentrations and probable origin of trace metals in the existing groundwater resources (Mirzabeygi et al. 2017; Shankar 2019; Ukah et al. 2019).

The use of several metal and environmental risk indices will offer comprehensive health risks coupled with HM ingestion via drinking water by the populace, allowing for a better understanding of the effects of HMs in water resources. Children, for instance, was reported to be the most responsive age group as a result of their physiological and behavioral patterns (Cao et al. 2015; Tripti et al. 2019). As a result, evaluating and considering the similarities/contrast in the health risks of different age groups are critical duties in monitoring the health condition of residents in a given specific area. Researchers have studied at the physicochemical and HMs content of shallow groundwater sources (Ganiyu et al. 2017; Ling and Zhang 2017; Akoto et al. 2019; Przydatek and Kanownik 2019) and the levels of dissolved HMs in surface/groundwater bodies (Ganiyu et al. 2017; Akoto et al. 2019; Gaokar and Matta 2019; Egbueri 2020). Exposure of human beings to metal sources in the surroundings and the health risks associated with it is also adequately reported (Bhutiani et al. 2017; Gu and Gao 2018; Ogundele et al. 2019; Kumar et al. 2020a, b).

Hand-dug wells in comparison with deep boreholes are relatively cheap to construct, require fewer numbers of workforces, make use of low-scale technology, and can be sited in most geological and urban settings (Egboka et al. 1988; Ayantobo et al. 2013; Mbaka et al. 2017). Hand-dug well is a circular hole with diameter approximately (1-1.8 m) large enough to allow for easy drawing out of water with the aid of drawer and rope, in few cases with manually operated mechanical pulley form (Orebiyi et al. 2010; Egboka et al. 1988; Mbaka et al. 2017). Kim and Park (2016) classified well with depth $<30 \mathrm{~m}$ as shallow well; $30 \mathrm{~m}<$ depth $<80 \mathrm{~m}$ as intermediate well and deep well with depth of more than $80 \mathrm{~m}$. Shallow hand-dug wells are the most common source of water in most urban, suburban, and peri-urban areas in Nigeria (Orebiyi et al. 2010; Amadi et al. 2013).

Ibadan, the capital city of Oyo state, southwest Nigeria has history of prevalent scarcity of pipe-borne water. It is continually growing both in human population and level of urbanization, which result in the sprawling of buildings in the outskirts. Ibadan is a major city in southwest part of Nigeria that was for a long time allowed to grow without a 
master plan (Areola and Ikporukpo 2018). The present study was carried out within Ibadan, which has a combinatorial setting of traditional core (urban slum), suburban, and periurban components (Adeleye and Olayiwola 2016). Built-up areas (traditional core areas) in Ibadan are characterized by overcrowded urban slums, derelict houses, and low-quality houses with little or no compliance to urban development and planning regulations. On the other hand, urban areas are characterized with well-defined/better planned residential buildings than in the traditional core areas (Adelekan 2016). Peri-urban areas (PUA) are settlements found on the border of cities and towns and are on switch to be included into urban areas (Orebiyi et al. 2010; Adelekan et al. 2014). The PUAs of Ibadan metropolis are relatively low-density areas with better arranged houses, mainly single apartments and flats. For this study, shallow hand-dug wells with depths $<30 \mathrm{~m}$ in selected built-up area (BUA/TCA), i.e., high-density residential area, urban area (UA), i.e., mediumdensity area and PUA (low-density area) were investigated for levels of metallic elements in groundwater. The aim of this study was to evaluate the quality of water by assessing selected trace metals in groundwater from three different residential areas within Ibadan using an urban pattern classification system. The study's goals are: assessment of water quality through the concentration and extent of metals contamination in shallow groundwater sources based on Ibadan's urban planning, determination of suitability for drinking, identification of potential contaminants, assessment of health and environmental risks associated with drinking of heavy metal-polluted water, and investigation of the interrelationship between studied water parameters in different residential areas within Ibadan metropolis.

\section{Materials and methods}

\section{Site description}

Ibadan lies within latitudes $7^{\circ} 20^{\prime}-7^{\circ} 40^{\prime}$ and longitudes $3^{\circ} 35^{\prime}-4^{\circ} 10^{\prime}$. It represents the high point of pre-colonial urban development in southwest Nigeria and was once described as the largest city in Africa (Lloyd and Mabogunje 1968). Ibadan still remains as the largest indigenous urban city in sub-Saharan Africa (Adelekan et al. 2014). It is the second most populated city after Lagos in Nigeria with an estimated population of 2,550,993 according to the national population commission (NPC) of 2006 (NPC 2010; Adelekan 2016). Ibadan city covers a total land area of 3123 $\mathrm{km}^{2}$ out of which about $15 \%\left(468.45 \mathrm{~km}^{2}\right)$ is classified as peri-urban (Adelekan et al. 2014; Wahab and Popoola 2018). Urban growth in Ibadan has been linked with a process of peri-urbanization, which then resulted in areas earlier characterized as rural areas being integrated into peri-urban and locations (Ayantobo et al. 2013; Adelekan et al. 2014). With a mean annual rainfall of about $1230 \mathrm{~mm}$ and a mean maximum temperature of $32{ }^{\circ} \mathrm{C}$, Ibadan has a humid and subhumid typical climate of southwest Nigeria.

\section{Geological setting}

The study area falls within the basement complex formation and consists mainly of Precambrian metamorphic rocks with little intrusions of Jurassic granites and porphyries (Okunlola et al. 2009; Bolarinwa 2017). The meta-sedimentary eries quartzites, banded gneiss, augen gneisses, and migmatites that make up the gneiss-migmatite complex are the most common rock types. Pegmatite, quartz, aplites, amphibolites, and xenoliths are some of the minor rock types (Okunlola et al. 2009). Groundwater presence, movement, and storage are present in usable quantity in the weathered and fractured portions of basement complex formation (Clark 1985; Olorunfemi and Fasuyi 1993; Akanbi 2018). Figure 1 is the geological map showing the rock types that underlie the study areas and water sampling locations.

\section{Description of well type in the study area}

Among the noticeable features for majority of sampled handdug wells in selected high density area (TCA) are wells not lined with either slotted or non-perforated concrete rings in the sidewalls, use of corroded aluminum/iron roofing sheet and wood materials as well cover and well ages exceeding 100 years. However, in the investigated PUA (low-density residential area), the sampled hand-dug wells were characterized with concrete ring linings, circular painted steel as well cover, well head protected by plastered cement/steel slab, presence of extra concrete ring from the ground surface acting as fence/barrier to surface contaminants and year of construction not exceeding fifteen (15) years. The sampled hand-dug wells in medium density area (urban area (UA)) comprise both lined and unlined ones and had year of construction (well age) within 20-50 years. The selected medium density area is within the vicinity of Ona River. The well data such as depth and water level during the time of collection of samples were noted and recorded while information about year of construction of wells and depth were provided by the well owners (Table 1). The longitude, latitude, and elevation of each sampling point were taken with the aid of handheld etrex 10 Garmin GPS equipment. The location map of water sampling point is shown in Fig. 2.

\section{Water sampling and analyses}

Fifteen (15) water samples were collected from 15 shallow groundwater sources (depths $<30 \mathrm{~m}$ ) within three areas (TCA, UA, and PUA) in Ibadan metropolis. The 


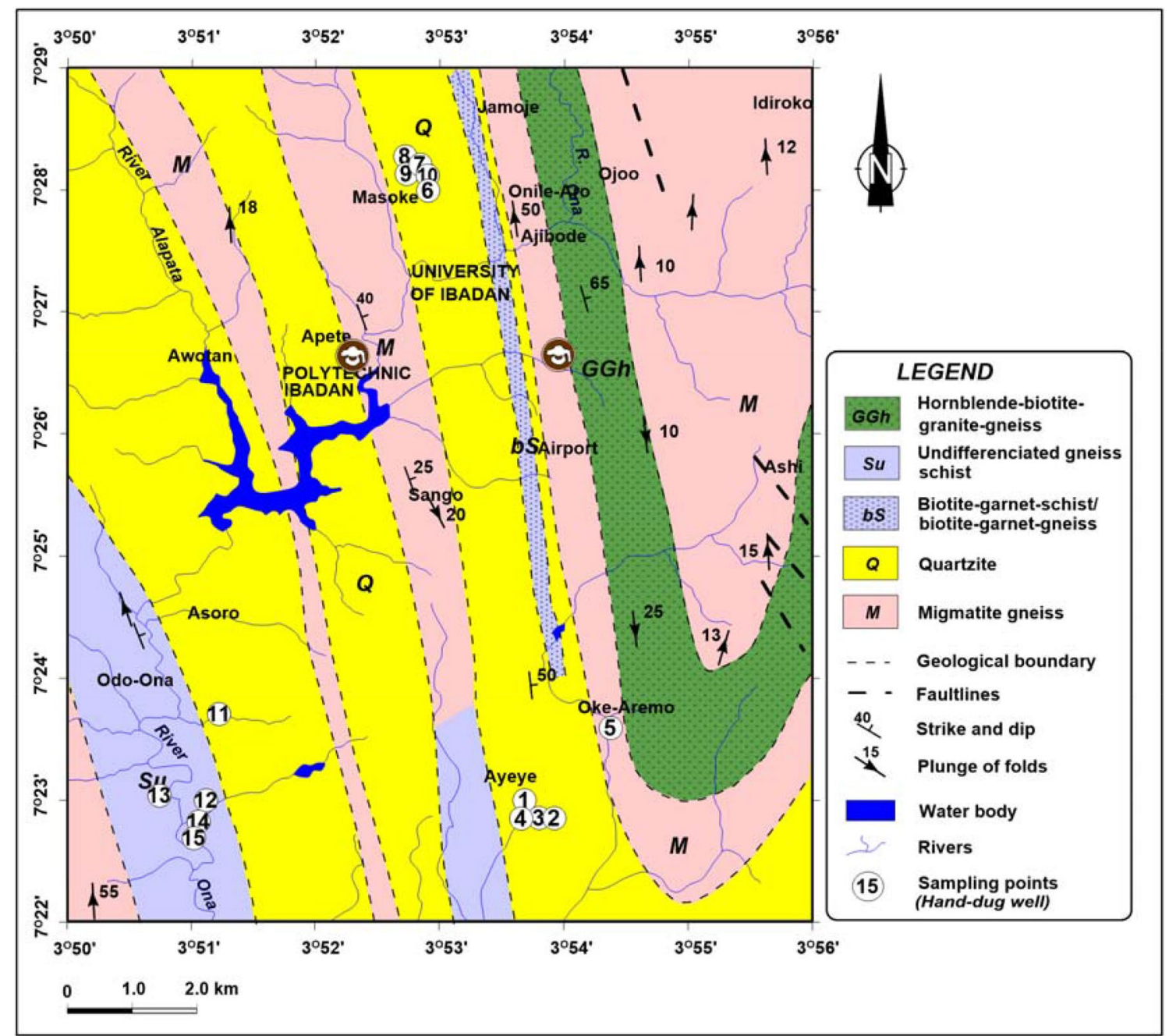

Fig. 1 Geological map showing the rock type that underlies the study area and water sampling locations (after NGSA 2016)

concentration of each analyzed quality indicator in each water sample is presented in the study. Water samples from five hand-dug wells with depths ranging from 0.7 to $6.2 \mathrm{~m}$ were collected from TCA and labeled S1-S5; S6-S10 were collected from another five wells with depths varying from 16.8 to $25.6 \mathrm{~m}$ in PUA, while S11-S15 were collected from five wells in UA with depths varying from 5.8 to $10.0 \mathrm{~m}$.

Water samples were collected in 2-L polyvinyl chloride bottles for heavy metal analyses. After collecting the water samples, each sampling bottle's cap was tightly screwed on to prevent leakage (Odukoya and Abimbola 2010; Ganiyu et al. 2018). Unwanted minerals were removed from the collected groundwater samples using a $0.45-\mathrm{m}$ membrane filter. Before beginning chemical analysis, the water samples were kept in an ice-crested cooler to prevent any kind of chemical/ biological reaction prior to chemical analysis (Ukah et al. 2019). The water chemistry laboratory of the Institute of Agricultural Research and Training (IAR\&T), Moor Plantation, Ibadan, Nigeria, conducted the quantitative chemical analysis. Trace metals, viz. $\mathrm{Zn}, \mathrm{Fe}, \mathrm{Pb}, \mathrm{Cd}$, and $\mathrm{Mn}$, were analyzed using atomic absorption spectrophotometer (AAS Buck 200, Germany) (Bhutiani et al. 2017; Popoola et al. 2019; Egbueri et al. 2020). TDS was measured in situ using a portable TDS meter (HM Digital COM-100).

\section{Heavy metal pollution index}

Several pollution indices can be employed to assess the degree to which trace elements contaminate water resources (Devanesan et al. 2017; Rahman et al. 2020; Kumar et al. 2020b). The integrated index method is used in the present study to evaluate heavy metal contamination in groundwater. The pollution indicators such as contamination factor $(\mathrm{CF})$, pollution load index (PLI), degree of contamination (DoC), quantification of contamination (QoC), modified degree of contamination (mDoC), enrichment factor $(\mathrm{EF})$, and geoaccumulation index $\left(I_{\text {geo }}\right)$ are some of the contamination indicators considered in the study (Table 2). 
Table 1 Well data for BUA, PUA, and UA water samples in Ibadan metropolis

\begin{tabular}{|c|c|c|c|c|}
\hline Well no. & Longitude and latitude & Total depth (m) & $\begin{array}{l}\text { Depth to water } \\
\text { table }(\mathrm{m})\end{array}$ & Sample code \\
\hline BUA1 & $\begin{array}{l}7^{\circ} 22^{\prime} 53.6^{\prime \prime} \\
3^{\circ} 53^{\prime} 45.0^{\prime \prime}\end{array}$ & 5.6 & 4.7 & $\mathrm{~S} 1$ \\
\hline BUA2 & $\begin{array}{l}7^{\circ} 22^{\prime} 51.3^{\prime \prime} \\
3^{\circ} 53^{\prime} 47.4^{\prime \prime}\end{array}$ & 5.2 & 4.4 & $\mathrm{~S} 2$ \\
\hline BUA3 & $\begin{array}{l}7^{\circ} 22^{\prime} 50.9^{\prime \prime} \\
3^{\circ} 53^{\prime} 56.7^{\prime \prime}\end{array}$ & 6.2 & 5.7 & S3 \\
\hline BUA4 & $\begin{array}{l}7^{\circ} 22^{\prime} 51.5^{\prime \prime} \\
3^{\circ} 53^{\prime} 44.6^{\prime \prime}\end{array}$ & 5.4 & 5.0 & $\mathrm{~S} 4$ \\
\hline BUA5 & $\begin{array}{l}7^{\circ} 23^{\prime} 35^{\prime \prime} \\
3^{\circ} 54^{\prime} 22^{\prime \prime}\end{array}$ & 0.7 & 0.6 & S5 \\
\hline PUA1 & $\begin{array}{l}7^{\circ} 28^{\prime} 51.5^{\prime \prime} \\
3^{\circ} 53^{\prime} 47.4^{\prime \prime}\end{array}$ & 16.8 & 7.3 & S6 \\
\hline PUA2 & $\begin{array}{l}7^{\circ} 28^{\prime} 10.0^{\prime \prime} \\
3^{\circ} 52^{\prime} 48.7^{\prime \prime}\end{array}$ & 20.4 & 6.4 & S7 \\
\hline PUA3 & $\begin{array}{l}7^{\circ} 28^{\prime} 14.4^{\prime \prime} \\
3^{\circ} 52^{\prime} 44.0^{\prime \prime}\end{array}$ & 18 & 9.2 & S8 \\
\hline PUA4 & $\begin{array}{l}7^{\circ} 28^{\prime} 09.5^{\prime \prime} \\
3^{\circ} 52^{\prime} 47.3^{\prime \prime}\end{array}$ & 22.8 & 10.1 & S9 \\
\hline PUA5 & $\begin{array}{l}7^{\circ} 28^{\prime} 08.2^{\prime \prime} \\
3^{\circ} 52^{\prime} 51.9^{\prime \prime}\end{array}$ & 25.2 & 2.7 & S10 \\
\hline UA1 & $\begin{array}{l}7^{\circ} 23^{\prime} 43.2^{\prime \prime} \\
3^{\circ} 53^{\prime} 11.9^{\prime \prime}\end{array}$ & 6.0 & 2.1 & S11 \\
\hline UA2 & $\begin{array}{l}7^{\circ} 22^{\prime} 58.2^{\prime \prime} \\
3^{\circ} 51^{\prime} 06.9^{\prime \prime}\end{array}$ & 6.2 & 5.8 & $\mathrm{~S} 12$ \\
\hline UA3 & $\begin{array}{l}7^{\circ} 23^{\prime} 03.2^{\prime \prime} \\
3^{\circ} 50^{\prime} 43.9^{\prime \prime}\end{array}$ & 6.2 & 5.2 & $\mathrm{~S} 13$ \\
\hline UA4 & $\begin{array}{l}7^{\circ} 22^{\prime} 50.2^{\prime \prime} \\
3^{\circ} 51^{\prime} 03.9^{\prime \prime}\end{array}$ & 10 & 3.7 & S14 \\
\hline UA5 & $\begin{array}{l}7^{\circ} 22^{\prime} 45.0^{\prime \prime} \\
3^{\circ} 51^{\prime} 03.9^{\prime \prime}\end{array}$ & 7.0 & 6.6 & S15 \\
\hline
\end{tabular}

\section{Potential health risk assessment of metals in groundwater samples}

The evaluation of the probable extent of undesirable health effects and their likelihood of happening due to the use of contaminated groundwater over a lifetime is required for the evaluation of health risk via oral intake pathway (Osipova et al. 2015; Ogundele et al. 2019). The most common route for population's exposure to heavy metals is via ingestion pathway (Paul et al. 2019; Egbueri and Mgbenu 2020).

The chronic daily intake (CDI) of metals in groundwater via oral ingestion route was established by:

$\mathrm{CDI}=\frac{C \times \mathrm{WIR} \times \mathrm{EF} \times \mathrm{ED}}{\mathrm{BW} \times \mathrm{AT}}$

where $C$ represents the concentration of metal in water $(\mathrm{mg} / \mathrm{l})$, WIR signifies the oral ingestion rate $(0.75,1$, and $2 \mathrm{~L} /$ day for infant, child, and adult, respectively (Egbueri 2020), EF is the exposure frequency in the water (365 days/ year), $\mathrm{ED}$ is the exposure duration time (70 years as adult ED, while 10 years $=$ child ED) $($ Kumar et al. 2020b), BW (in $\mathrm{kg}$ ) denotes the mean body weight (equivalent to $5 \mathrm{~kg}$, $10 \mathrm{~kg}$, and $60 \mathrm{~kg}$ for infant, child, and adult, respectively), and AT (the averaging time in days) (equals 3650 days and 25,550 days for child and adult, respectively). Using $\mathrm{AT}=\mathrm{EF} \times \mathrm{ED}$, Eq. (1) reduces to

$\mathrm{CDI}=\frac{C \times \mathrm{WIR}}{\mathrm{BW}}$

The non-carcinogenic risk calculated as hazardous quotient (HQ) in contaminated groundwater for non-cancer risk is evaluated by adopting the expression:

$\mathrm{HQ}_{i}=\frac{\mathrm{CDI}}{\mathrm{RfD}}$

where RfD signifies the oral reference dose of a specific metal (mg/kg/day). The RfD equivalent for $\mathrm{Cd}, \mathrm{Zn}, \mathrm{Fe}$, $\mathrm{Mn}$ and $\mathrm{Pb}$ is $0.001,0.3,0.7,0.14$, and 0.0036 , respectively (Duggal et al. 2017; Enuneku et al. 2018; Mgbenu 


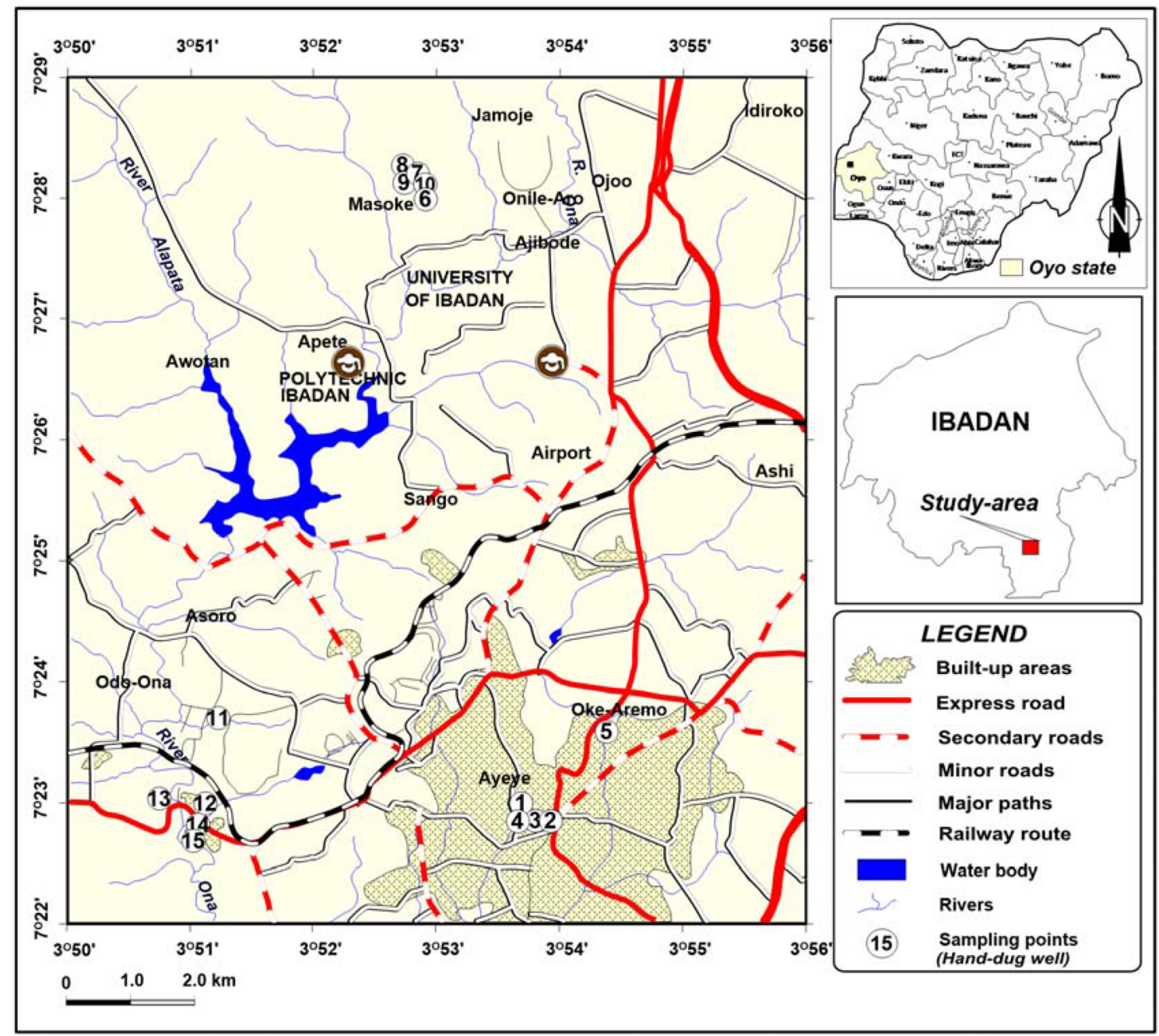

Fig. 2 Location map showing the access roads and water sampling points ( adapted from Google Earth Imagery 2019)

and Egbueri 2019; Egbueri 2020). The final value for the non-carcinogenic risk evaluation is the hazard index (HI) (Egbueri and Mgbenu 2020; Kumar et al. 2020b). It assists in determination of the total effects of all dissolved HMs (Egbueri and Mgbenu 2020) in analyzed water. The HI value is the summation of all donating HQs caused by ingested HMs in water:

$\mathrm{HI}=\sum_{i=\}}^{n} \mathrm{HQ}_{i}$

For non-carcinogenic risk, $\mathrm{H} 1>1$ signifies a high potential health risk; it suggests that the non-carcinogenic risk of ingesting a specific metal surpasses the acceptable safe limit (Ukah et al. 2019). However, HI less than unity means that the non-carcinogenic health risk lies within the acceptance limit (Afrifa et al. 2013; Kladsomboon et al. 2019; Wu et al. 2019; Egbueri and Mgbenu 2020).

\section{Cancer risk (CR)}

The probability of cancer risk of drinking groundwater was evaluated as the incremental likelihood of human being developing cancer over a life span, resulting from the exposure to a prospective carcinogenic element (Enuneku et al. 2018; Ukah et al. 2019; Egbueri and Mgbenu 2020). The CR is computed using Eq. (5):

$\mathrm{CR}=\mathrm{ADD} \times \mathrm{SF}_{i}$

where $\mathrm{SF}_{i}$ is the slope factor (mg/kg/day). The tolerable CR value is within the range $1 \times 10^{-6}$ to $1 \times 10^{-4}$ (USEPA 2012; Rahman et al. 2018; Ukah et al. 2019; Egbueri and Mgbenu 2020). 


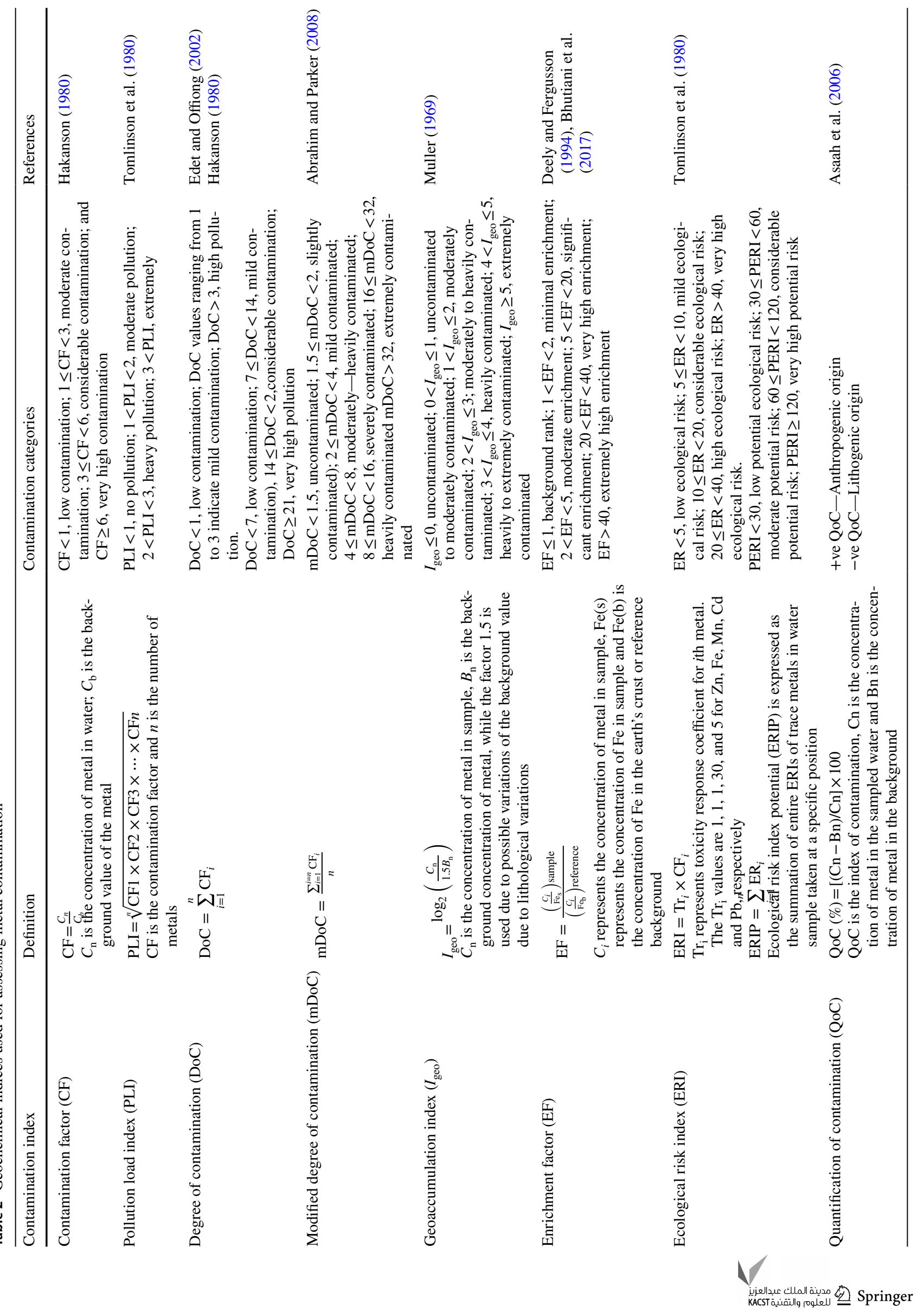




\section{Statistical analyses}

Data from laboratory analysis of water samples were subjected to descriptive statistics, Pearson's correlation matrix, and multivariate statistical analysis (MSA). Pearson correlation is a statistical method for determining and measuring the association between two variables. The sign of the correlation coefficient value shows whether the relationship is positive or negative, while the absolute value of correlation coefficient reveals the linear relationship's strength (Saleem et al. 2012; Amfo-Otu et al. 2014; Selvakumar et al. 2017; Ukah et al. 2019).

The MSA is a statistical method that can be employed to identify the main quality indicator(s) affecting the quality of a soil/water system's soil/water system's soil/water system's soil/water system's soil/water system's soil/water system's soil/water system's soil/water system's soil/water system's soil/water system's soil/water system (Barzegar et al. 2019; Singh and Singh 2019; Adhikari and Mal 2019). The factor analysis allows the size of the initial data set to be reduced to a lesser number of factors devoid of sacrificing the original data set's inherent information (Panthi et al. 2017; Paul et al. 2019; Adhikari and Mal 2019). Because of the normal distribution of raw data and the various units of measurement of analyzed parameters, the original data have to undergo normalization and standardization for proper factor analysis (Barakat et al. 2016; Barzegar et al. 2019). Factors with eigenvalues greater than one were selected and then varimax-rotated using Kaiser normalization (Kaiser 1960; Usman et al. 2014; Egbueri 2020). The hierarchical cluster analysis (HCA) can be used for grouping data into classes according to characteristics, sources, and features that are similar or dissimilar (Hamid et al. 2016; Hajigholizadeh and Melesse 2017). The HCA can be obtained by employing the most widely used data clustering method and application of Ward's method of linkage (Bilgin and Konane 2016; Barzegar et al. 2019; Liu et al. 2021). Dendrogram is a pictorial representation of the CA result based on either the analyzed parameters or sampling locations.

\section{Results and discussion}

\section{Levels of HMs and TDS in groundwater samples}

The mean concentrations of studied HMs and TDS in sampled groundwater are presented in Table 3 . The concentrations of $\mathrm{Zn}(\mathrm{mg} / \mathrm{L})$ ranged between $0.53-5.73,0.67-3.62$ and 2.95-8.26 for TCA, PUA, and UA, respectively. Sixty percentage of water samples were higher than the recommended permissible limit of $3.00 \mathrm{mg} / \mathrm{L}$ (NIS 2015; WHO 2015). The concentrations of $\mathrm{Fe}$ in the groundwater within TCA, PUA, and UA in $\mathrm{mg} / \mathrm{L}$ were $0.16-3.28,0.21-1.24$, and 1.21-3.94, respectively (Table 2). $86.7 \%$ of the samples from investigated residential locations were above $0.30 \mathrm{mg} / \mathrm{L}$ recommended for drinking purpose. The concentrations of $\mathrm{Pb}$ in groundwater within TCA, PCA, and UA in $\mathrm{mg} / \mathrm{L}$ were $0.44-0.76,0.48-0.68$ and $0.67-0.84$, respectively. All the groundwater samples in the residential areas were above the acceptable limit of $0.01 \mathrm{mg} / \mathrm{L}$ (WHO 2015). The concentration of cadmium in $\mathrm{mg} / \mathrm{L}$ ranged from 0.33 to 0.58 , 0.36 to 0.50 , and 0.51 to 0.64 in groundwater within TCA, PUA, and UA, respectively. The levels of $\mathrm{Cd}$ were higher than the acceptable limit of 0.003 in all the groundwater samples. The concentration of manganese $(\mathrm{mg} / \mathrm{L})$ in groundwater from shallow wells within TCA, PUA, and UA was less than $0.2 \mathrm{mg} / \mathrm{L}$ recommended by $\mathrm{WHO}$ as permissible limit for consumption purpose. These low values of $\mathrm{Mn}^{2+}$ in $\mathrm{S}_{1}-\mathrm{S}_{15}$ may be due to the fact that $\mathrm{Mn}^{2+}$ concentration in groundwater increases with depth of the well (Barzegar et al. 2015). All the wells sampled for this study were shallow wells with depths $<30 \mathrm{~m}$. The TDS ranged between 44.37 and $113.46,53.65-87.38$ and $67.35-136.59 \mathrm{in} \mathrm{mg} / \mathrm{L}$ within TCA, PUA, and UA, respectively. All the groundwater samples in the three residential locations had TDS values lower than $500 \mathrm{mg} / \mathrm{L}$ recommended by WHO 2015 guidelines for drinking water. Based on TDS values, all groundwater samples in representative BUA, PUA, and UA can be classified as freshwater since their TDS values lie below $1000 \mathrm{mg} / \mathrm{L}$ (Bolarinwa 2017; Ukah et al. 2019). In general, the least value of TDS (44.4 mg/L) was found in S5 (confined spring water) located within TCA in migmatite bedrock setting, while relatively the highest value of TDS (136.6 mg/L) was observed in $\mathrm{S}_{13}$ (water sample from an unlined well in UA) located within the undifferentiated gneiss schist setting. It was observed that lowest and highest values of TDS in $\mathrm{S}_{5}$ and $\mathrm{S}_{13}$ correspond with the minimum and maximum values of $\mathrm{Fe}^{2+}$ in analyzed water samples. The fittingness of analyzed water samples for ingestion use was evaluated through the comparisons of HM results with the acceptable safe drinking water quality standards (WHO 2015). The concentrations of zinc, iron, lead, and cadmium were above permissible standards in $60 \%, 86.7 \%, 100 \%$, and $100 \%$ of water samples, respectively. However, values of TDS and Mn were less than WHO 2015 permissible limits for drinking purpose.

\section{Statistical analysis of groundwater data}

The details of descriptive statistics of water parameters from the TCA, PUA, and UA settings of Ibadan are presented in Table 4, while Table 5 presents the results of ANOVA to examine significant variations in the observed parameters among the 3 locations. Table 6 presents the observed correlation coefficient results of water quality parameters of studied groundwater samples, while 
Table 3 Results of heavy metals and TDS in collected groundwater samples of Ibadan metropolis

\begin{tabular}{lllllll}
\hline Sample code & Zinc $(\mathrm{mg} / \mathrm{L})$ & Iron $(\mathrm{mg} / \mathrm{L})$ & $\begin{array}{l}\text { Man- } \\
\text { ganese } \\
(\mathrm{mg} / \mathrm{L})\end{array}$ & Lead $(\mathrm{mg} / \mathrm{L})$ & Cadmium $(\mathrm{mg} / \mathrm{L})$ & $\mathrm{TDS}(\mathrm{mg} / \mathrm{L})$ \\
\hline $\mathrm{S}_{1}$ & 5.70 & 3.22 & 0.04 & 0.76 & 0.58 & 86.98 \\
$\mathrm{~S}_{2}$ & 5.73 & 3.28 & 0.04 & 0.74 & 0.58 & 113.46 \\
$\mathrm{~S}_{3}$ & 1.63 & 0.50 & 0.03 & 0.55 & 0.42 & 69.83 \\
$\mathrm{~S}_{4}$ & 1.65 & 0.51 & 0.03 & 0.53 & 0.42 & 70.09 \\
$\mathrm{~S}_{5}$ & 0.53 & 0.16 & 0.02 & 0.44 & 0.33 & 44.37 \\
$\mathrm{~S}_{6}$ & 0.67 & 0.21 & 0.02 & 0.48 & 0.36 & 53.65 \\
$\mathrm{~S}_{7}$ & 3.57 & 1.20 & 0.03 & 0.68 & 0.50 & 86.98 \\
$\mathrm{~S}_{8}$ & 3.47 & 1.24 & 0.03 & 0.66 & 0.49 & 85.67 \\
$\mathrm{~S}_{9}$ & 1.57 & 0.33 & 0.03 & 0.54 & 0.41 & 68.92 \\
$\mathrm{~S}_{10}$ & 3.62 & 0.91 & 0.03 & 0.67 & 0.50 & 87.38 \\
$\mathrm{~S}_{11}$ & 6.15 & 2.57 & 0.04 & 0.77 & 0.59 & 117.10 \\
$\mathrm{~S}_{12}$ & 5.51 & 2.26 & 0.04 & 0.75 & 0.578 & 110.04 \\
$\mathrm{~S}_{13}$ & 8.05 & 3.94 & 0.04 & 0.80 & 0.61 & 136.59 \\
$\mathrm{~S}_{14}$ & 2.92 & 1.21 & 0.03 & 0.67 & 0.51 & 67.35 \\
$\mathrm{~S}_{15}$ & 8.26 & 3.93 & 0.04 & 0.84 & 0.64 & 119.81 \\
$\mathrm{WHO}_{\mathrm{NHO}}$ (2015) limit & 3.00 & 0.30 & 0.20 & 0.01 & 0.003 & 500 \\
\hline
\end{tabular}

Table 7 shows the model summary of categorical PCA. Table 8 shows the centroid coordinates and total variance as Table 9 shows the factor loading and eigenvalue of single extracted component. The average concentration value and coefficient of variation for each analyzed parameter as presented in Table 4 revealed that there were statistically no significant differences in all analyzed parameters at $5 \%$ level. Table 4 further reveals that the average concentration of each assessed quality parameter at UA is relatively higher than that of PUA and TCA in Ibadan. However, the value of C.V. of each parameter at TCA is relatively higher than that of PUA and UA residential locations. The results of ANOVA (Table 5) show that mean $\mathrm{Zn}$ concentration of the collected water samples varied from $2.58 \pm 1.37$ to $6.18 \pm 2.17$ with the highest value observed in samples collected from UA, while the least value was observed in samples from PUA. The result further reveals that mean $\mathrm{Zn}$ concentration of water samples collected from UA was significantly higher than those of the other two locations. The concentration of $\mathrm{Fe}$ in groundwater samples ranged from $0.78 \pm 0.48$ to $2.78 \pm 1.17$ with the highest value recorded in samples collected from UA, while the least value was observed in samples from PUA. Moreover, the result shows that mean Fe concentration of groundwater samples from UA was significantly higher than those of water samples collected from PUA. The mean values of manganese varied from $0.03 \pm 0.01$ to $0.04 \pm 0.00$ with the highest concentration observed in samples from UA, while the samples from traditional core area (TCA) and PUA both have approximately equal mean concentration of manganese. The result further shows that mean concentration of
Mn in water samples collected from UA was significantly higher than those of the samples from the other two locations (TCA and PUA). The mean concentration of $\mathrm{Pb}$ in collected groundwater samples from the three locations varied from $0.60 \pm 0.14$ to $0.77 \pm 0.06$ with the highest concentration recorded in samples from UA, while the least concentration was observed in samples from TCA. Furthermore, the result reveals that mean $\mathrm{Pb}$ concentration of water samples collected from UA was significantly higher than those of the other two locations. Cadmium concentration varied from $0.46 \pm 0.06$ to $0.59 \pm 0.05$ with the highest concentration observed in water samples from UA, while the least concentration was recorded in groundwater samples from PUA. The result shows further that the mean value of $\mathrm{Cd}$ concentration in samples collected from UA was considerably higher than those of samples collected from the other two locations (i.e., TCA and PUA). The mean value of TDS in collected water samples ranged from $76.52 \pm 14.93$ to $110.18 \pm 25.84$ with the highest mean value recorded in samples collected from UA, while the least value was recorded in samples from PUA. Moreover, the result reveals that TDS of soil samples collected from UA was significantly higher than those of the PUA and TCA locations. From this result, it is observed that concentrations of the observed parameters did not differ significantly between water samples collected from TCA and PUA.

It can be seen from Table 6 that all the observed correlations showed that most of the studied HMs and TDS have significant relations with one another at $1 \%$ level. The correlation matrix (Table 5) revealed that every pair of assessed

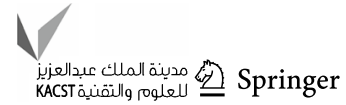


Table 4 Descriptive statistics of analyzed parameters in TCA, PUA, and UA of Ibadan metropolis

\begin{tabular}{|c|c|c|c|c|c|c|c|c|c|c|}
\hline \multirow[t]{2}{*}{ Parameters } & \multirow[t]{2}{*}{ Locations } & \multirow[t]{2}{*}{$N$} & \multirow[t]{2}{*}{ Mean } & \multirow[t]{2}{*}{ Std. deviation } & \multirow[t]{2}{*}{ Std. error } & \multicolumn{2}{|c|}{$\begin{array}{l}95 \% \text { confidence interval for } \\
\text { mean }\end{array}$} & \multirow[t]{2}{*}{ Minimum } & \multirow[t]{2}{*}{ Maximum } & \multirow[t]{2}{*}{ C.V } \\
\hline & & & & & & Lower bound & Upper bound & & & \\
\hline \multirow[t]{3}{*}{ Zinc } & Traditional core area & 5 & 3.05 & 2.48 & 1.11 & -0.03 & 6.13 & 0.53 & 5.75 & 81.30 \\
\hline & Peri-urban area & 5 & 2.58 & 1.37 & 0.61 & 0.88 & 4.28 & 0.67 & 3.62 & 53.20 \\
\hline & Urban area & 5 & 6.18 & 2.17 & 0.97 & 3.48 & 8.88 & 2.92 & 8.26 & 35.20 \\
\hline \multirow[t]{3}{*}{ Iron } & Traditional core area & 5 & 1.53 & 1.57 & 0.70 & -0.42 & 3.49 & 0.16 & 3.28 & 102.50 \\
\hline & Peri-urban area & 5 & 0.78 & 0.48 & 0.22 & 0.18 & 1.38 & 0.21 & 1.24 & 62.10 \\
\hline & Urban area & 5 & 2.78 & 1.17 & 0.52 & 1.33 & 4.23 & 1.21 & 3.94 & 41.90 \\
\hline \multirow[t]{3}{*}{ Manganese } & Traditional core area & 5 & 0.03 & 0.01 & 0.00 & 0.02 & 0.04 & 0.02 & 0.04 & 24.00 \\
\hline & Peri-urban area & 5 & 0.03 & 0.00 & 0.00 & 0.02 & 0.03 & 0.02 & 0.03 & 13.00 \\
\hline & Urban area & 5 & 0.04 & 0.00 & 0.00 & 0.03 & 0.04 & 0.03 & 0.04 & 8.20 \\
\hline \multirow[t]{3}{*}{ Lead } & Traditional core area & 5 & 0.60 & 0.14 & 0.06 & 0.43 & 0.78 & 0.44 & 0.76 & 23.10 \\
\hline & Peri-urban area & 5 & 0.61 & 0.09 & 0.04 & 0.49 & 0.72 & 0.48 & 0.68 & 14.90 \\
\hline & Urban area & 5 & 0.77 & 0.06 & 0.03 & 0.69 & 0.84 & 0.67 & 0.84 & 8.30 \\
\hline \multirow[t]{3}{*}{ Cadmium } & Traditional core area & 5 & 0.46 & 0.11 & 0.04 & 0.33 & 0.60 & 0.33 & 0.58 & 23.70 \\
\hline & Peri-urban area & 5 & 0.46 & 0.06 & 0.03 & 0.37 & 0.53 & 0.36 & 0.50 & 14.00 \\
\hline & Urban area & 5 & 0.59 & 0.05 & 0.02 & 0.52 & 0.65 & 0.51 & 0.64 & 8.30 \\
\hline \multirow[t]{3}{*}{ TDS } & Traditional core area & 5 & 76.95 & 25.45 & 11.39 & 45.33 & 108.56 & 44.37 & 113.46 & 33.10 \\
\hline & Peri-urban area & 5 & 76.52 & 14.93 & 6.68 & 57.98 & 95.06 & 53.65 & 87.38 & 19.50 \\
\hline & Urban area & 5 & 110.18 & 25.85 & 11.56 & 78.08 & 142.27 & 67.35 & 136.59 & 23.50 \\
\hline
\end{tabular}

Table 5 ANOVA result for analyzed parameters based on residential location

\begin{tabular}{lccc}
\hline Parameters & Traditional core area & Peri-urban area & Urban area \\
\hline Zinc & $3.05 \pm 2.48^{\mathrm{a}}$ & $2.58 \pm 1.37^{\mathrm{a}}$ & $6.18 \pm 2.17^{\mathrm{b}}$ \\
Iron & $\mathbf{1 . 5 3} \pm \mathbf{1 . 5 7 ^ { \mathrm { ab } }}$ & $0.78 \pm 0.48^{\mathrm{a}}$ & $2.78 \pm 1.17^{\mathrm{b}}$ \\
Manganese & $0.03 \pm 0.01^{\mathrm{a}}$ & $0.03 \pm 0.00^{\mathrm{a}}$ & $0.04 \pm 0.00^{\mathrm{b}}$ \\
Lead & $0.60 \pm 0.14^{\mathrm{a}}$ & $0.61 \pm 0.09^{\mathrm{a}}$ & $0.77 \pm 0.06^{\mathrm{b}}$ \\
Cadmium & $0.46 \pm 0.11^{\mathrm{a}}$ & $0.46 \pm 0.06^{\mathrm{a}}$ & $0.59 \pm 0.05^{\mathrm{b}}$ \\
TDS & $76.95 \pm 25.46^{\mathrm{a}}$ & $76.52 \pm 14.93^{\mathrm{a}}$ & $110.18 \pm 25.85^{\mathrm{b}}$ \\
\hline
\end{tabular}

Table shows mean \pm standard deviation values. Values along the same row with different superscripts are significantly different at $5 \%$ $(p<0.05)$ level. Bold depicts the three different residential locations used for this study

parameters (between two HMs/metal and TDS) correlate positively at $1 \%$ level $(p<0.01)$. This is an indication that all the analyzed metals were possibly from the same pollutant sources (Zarei et al. 2014; Vetrimurugan et al. 2017; Kumar et al. 2017; Egbueri 2019). Specifically, very strong direct association at $1 \%$ level $\left(r^{2}>0.9\right)$ in the matrix was noticed for $\mathrm{Fe}-\mathrm{Zn}, \mathrm{Mn}-\mathrm{Zn}, \mathrm{Mn}-\mathrm{Fe}, \mathrm{Pb}-\mathrm{Zn}, \mathrm{Pb}-\mathrm{Fe}, \mathrm{Zn}-\mathrm{Cd}$ and $\mathrm{Pb}-\mathrm{Cd}$ pairs. Similarly, highest determination coefficient $\left(r^{2}>0.9\right)$ at $1 \%$ level was also found between $\mathrm{Cd}-\mathrm{Fe}, \mathrm{Pb}-\mathrm{Mn}$, and $\mathrm{Cd}-\mathrm{Mn}$ pairs. Strong positive association between $\mathrm{Pb}$ and $\mathrm{Cd}$ concurs with similar result reported by Bhutiani et al. (2017), Mgbenu and Egbueri (2019) and Ukah et al. (2019). Very strong positive associations $\left(r^{2}>0.95\right)$ between $\mathrm{Zn}-\mathrm{Cd}$ pair and $\mathrm{Zn}-\mathrm{Pb}$ pair agree with the result of Aigberua et al. (2020). Similar positive association for Fe-Mn pair was also reported by Barzegar et al. (2015), Palmucci et al. (2016), and Kshetrimayum and Hegeu (2016). Strong positive relation between $\mathrm{Zn}-\mathrm{Mn}$ pair concurs with similar association reported by Vetrimurugan et al. (2017). A very strong direct
Table 6 Correlation coefficient matrix of analyzed heavy metals and TDS of groundwater samples

\begin{tabular}{lllllll}
\hline & Zinc & Iron & Manganese & Lead & Cadmium & TDS \\
\hline Zinc & 1 & & & & & \\
Iron & $.970^{* *}$ & 1 & & & \\
Manganese & $.969^{* *}$ & $.931^{* *}$ & 1 & & & \\
Lead & $.965^{* *}$ & $.914^{* *}$ & $.996^{* *}$ & 1 & \\
Cadmium & $.969^{* *}$ & $.927^{* *}$ & $.999^{* *}$ & $.997^{* *}$ & 1 & \\
TDS & $.950^{* *}$ & $.890^{* *}$ & $.915^{* *}$ & $.910^{* *}$ & $.915^{* *}$ & 1 \\
\hline
\end{tabular}

**Correlation is significant at the 0.01 level (2-tailed) 
Table 7 Model summary of categorical PCA

\begin{tabular}{|c|c|c|c|}
\hline \multirow[t]{2}{*}{ Dimension } & \multirow{2}{*}{$\begin{array}{l}\text { Cronbach's } \\
\text { alpha }\end{array}$} & \multicolumn{2}{|c|}{ Variance accounted for } \\
\hline & & $\begin{array}{l}\text { Total (eigen- } \\
\text { value) }\end{array}$ & $\%$ of variance \\
\hline 1 & 0.99 & 5.68 & 94.64 \\
\hline Total & 0.99 & 5.68 & 94.64 \\
\hline
\end{tabular}

Table 8 Centroid coordinates and total variance

\begin{tabular}{lcrrrr}
\hline & \multicolumn{2}{l}{ Centroid coordinates } & & \multicolumn{2}{l}{$\begin{array}{l}\text { Total (vector coordi- } \\
\text { nates) }\end{array}$} \\
\cline { 2 - 3 } \cline { 6 - 7 } \cline { 5 - 6 } & Dimension & Mean & & Dimension & Total \\
& 1 & & & 1 & \\
\hline Zinc & 0.98 & 0.98 & & .956 & 0.96 \\
Iron & 0.97 & 0.97 & & .903 & 0.90 \\
Manganese & 1.00 & 1.00 & & .976 & 0.98 \\
Lead & 0.98 & 0.98 & & .969 & 0.97 \\
Cadmium & 1.00 & 1.00 & & .972 & 0.97 \\
TDS & 0.93 & 0.93 & & .902 & 0.90 \\
Active total & 5.86 & 5.86 & & 5.678 & 5.68 \\
\% of Variance & 97.66 & 97.66 & & 94.637 & 94.64 \\
\hline
\end{tabular}

Table 9 Varimax-rotated component loadings in PCA

\begin{tabular}{lc}
\hline Variables & Factor 1 \\
\hline $\mathrm{Zn}(\mathrm{mg} / \mathrm{L})$ & 0.98 \\
$\mathrm{Mn}(\mathrm{mg} / \mathrm{L})$ & 0.99 \\
$\mathrm{Cd}(\mathrm{mg} / \mathrm{L})$ & 0.99 \\
$\mathrm{~Pb}(\mathrm{mg} / \mathrm{L})$ & 0.98 \\
$\mathrm{Fe}(\mathrm{mg} / \mathrm{L})$ & 0.95 \\
$\mathrm{TDS}(\mathrm{mg} / \mathrm{L})$ & 0.95 \\
Eigenvalue & 5.68 \\
Cumulative eigenvalue & 5.68 \\
$\%$ total variance & 95.69 \\
Cumulative \% & 94.64 \\
\hline
\end{tabular}

association in the correlation pair $\mathrm{Mn}-\mathrm{Cd}\left(r^{2}>0.95\right)$ agrees with the comparable association reported by Popoola et al. (2019) in their assessment of physicochemical properties of groundwater samples in industrial and residential locations in Lagos metropolis.

A strong positive association at $1 \%$ level occurs between TDS and each of analyzed metals. This is an indication that the dissolved HMs significantly influence the TDS of the collected water samples. Zhang et al. (2020) also reported positive correlation between TDS and Fe, and TDS and Mn in their assessment of groundwater quality in Shuangliao city, northeast China. Similar strong direct association between TDS and Zn was also obtained by Herngren et al. (2005). Furthermore, significant correlation between TDS and $\mathrm{Cd}\left(r^{2}>0.85\right)$ obtained in this study was also reported by Popoola et al. (2019).

The reliability analysis for PCA shows a good level of internal consistency among the items as the Cronbach's alpha value for the extracted component $\alpha=0.989$ (Table 7). Only one (1) component has eigenvalue over Kaiser's criterion of 1 , and this component accounts for $94.637 \%$ of the total variance in the data set. Each of the items contributes substantially to the principal component as each item has high mean coordinate value (Table 8). Moreover, the result of the component loadings shows that all the parameters have very high positive loadings on the extracted component (Table 9). Strong positive loadings of extracted factors in only PC imply lithogenic and anthropogenic sources of heavy metals in analyzed groundwater samples (Barzegar et al. 2017; Wagh et al. 2018). Based on the component loadings' scatter plot (Fig. 3), all the six items cluster together at the upper range of the extracted component. On the other hand, the biplot (Fig. 4) shows a large amount of variation among the cases (blue dots).

According to the dendrogram of assessed water quality parameters (Fig. 5a), only 1 cluster was identified and contains all the analyzed water quality parameters. This cluster is in agreement with elements that have strong positive loadings in only extracted component. The cluster branches of water sampling positions (Fig. 5b) show that three major clusters were created. The first cluster comprises $\mathrm{S}_{3}-\mathrm{S}_{6}$, and $S_{9}$, cluster 2 contains $S_{7}, S_{8}, S_{10}$ and $S_{14}$, while cluster 3 contains $S_{1}-S_{2}, S_{11}-S_{12}, S_{13}$ and $S_{15}$. Cluster 1 comprises water samples with $<2 \mathrm{mg} / \mathrm{L}$ of $\mathrm{Zn},<0.75 \mathrm{mg} / \mathrm{L}$ of $\mathrm{Fe},<0.03 \mathrm{mg} / \mathrm{L}$ of $\mathrm{Mn},<0.6 \mathrm{mg} / \mathrm{L}$ of $\mathrm{Pb}$ and $<0.45 \mathrm{mg} / \mathrm{L}$ of cadmium. Cluster 2 comprises samples with similar characteristics such as $\mathrm{Pb}$ values of $\approx 0.7 \mathrm{mg} / \mathrm{L}$ and $\mathrm{Cd}$ values of $\approx 0.5 \mathrm{mg} / \mathrm{L}$. Cluster 3 contains samples with $>5 \mathrm{mg} / \mathrm{L}$ of $\mathrm{Zn},>2 \mathrm{mg} / \mathrm{L}$ of $\mathrm{Fe},>0.035 \mathrm{mg} / \mathrm{L}$ of $\mathrm{Mn}$ and $>7 \mathrm{mg} / \mathrm{L}$ of $\mathrm{Pb}^{2+}$ ions.

\section{Extent of metal pollution}

The results of degree of metal pollution based on CF, EF, PLI, and $I_{\text {geo }}$ are listed in Table 10. According to Hakanson (1980) classification approach, the $\mathrm{CF}$ values for $\mathrm{Pb}, \mathrm{Cd}$, and $\mathrm{Mn}$ were found to be in the range of $\mathrm{CF}<1$, an indication of low contamination of these metals in $\mathrm{S}_{3}-\mathrm{S}_{6}$ and $\mathrm{S}_{9}$, while the trio metals were in moderate contamination class $(1 \leq \mathrm{CF}<3)$ in samples $\mathrm{S}_{1}-\mathrm{S}_{2}, \mathrm{~S}_{7}-\mathrm{S}_{8}$ as well as $\mathrm{S}_{10}-\mathrm{S}_{15}$. However, $\mathrm{Fe}$ was found in low contamination state in samples $\mathrm{S}_{3}-\mathrm{S}_{6}$ and $\mathrm{S}_{9}-\mathrm{S}_{10}$, while $\mathrm{Zn}$ levels were in low contamination status in $S_{3}-S_{6}, S_{9}$ as well as $S_{14}$. However, all the analyzed $\mathrm{HMs}$ in samples $\mathrm{S}_{1}-\mathrm{S}_{2}$ (in TCA), $\mathrm{S}_{7}-\mathrm{S}_{8}$ (in PUA) and $\mathrm{S}_{11}-\mathrm{S}_{12}$ within $\mathrm{UA}$ fall within moderate contamination 
class according to Hakanson (1980) classification. It must also be noted that $\mathrm{Fe}$ in $\mathrm{S}_{13}$ and $\mathrm{S}_{15}$ belongs to considerable contamination class. The values of PLI for the studied HMs in groundwater samples as presented in Table 10 varied from 0.55 to 1.47. The highest value of PLI was found in $S_{15}$ (1.47), while the least value of PLI was found in $S_{5}$ (0.55). In terms of PLI values, samples $S_{3}-S_{6}$ as well as $\mathrm{S}_{9}$ are characterized with $\mathrm{PLI}<1$, indicating nil pollution condition. However, PLI values were greater than unity in $\mathrm{S}_{1}-\mathrm{S}_{2}, \mathrm{~S}_{7}-\mathrm{S}_{8}$ and $\mathrm{S}_{10}-\mathrm{S}_{15}$, suggesting pollution state of mentioned samples. The enrichment factor (EF) for each HM in the study area is presented in Table 10. There is background enrichment of $\mathrm{Cd}, \mathrm{Pb}$, and $\mathrm{Mn}$ in $\mathrm{S}_{1}-\mathrm{S}_{2}, \mathrm{~S}_{7}-\mathrm{S}_{8}$, and $\mathrm{S}_{11}-\mathrm{S}_{15}$ but moderately enriched in $S_{5}-S_{6}$. However, $Z n$ exhibited background concentration in $\mathrm{S}_{1}-\mathrm{S}_{2}$ and $\mathrm{S}_{11}-\mathrm{S}_{5}$ and minor enrichment in $\mathrm{S}_{3}-\mathrm{S}_{10}$. Anthropogenic sources of $\mathrm{Pb}$ in samples $S_{3}-S_{6}$ as well as $S_{9}$ were discovered by their EF values greater than 1.5. Lithogenic inputs of $\mathrm{Pb}$ in $\mathrm{S}_{7}-\mathrm{S}_{8}, \mathrm{~S}_{10}-\mathrm{S}_{12}$ as well as $\mathrm{S}_{14}$ were indicated by their EF values in the range of 0.5-1.5 (Nowrouzi and Pourkhabbaz 2014). The sources of $\mathrm{Cd}$ in samples $\mathrm{S}_{3}-\mathrm{S}_{6}$ and in $\mathrm{S}_{9}$ were found to be anthropogenic origins, while $C d$ in $S_{7}-S_{8}, S_{10}-S_{12}$ as well as $S_{14}$ had lithogenic source. The Mn dissolution in groundwater samples $\mathrm{S}_{7}-\mathrm{S}_{8}, \mathrm{~S}_{10}-\mathrm{S}_{12}$ and $\mathrm{S}_{14}$ was discovered to be due to lithogenic/crustal source, while $\mathrm{S}_{3}-\mathrm{S}_{6}$ and $\mathrm{S}_{9}$ had Mn contents to be from anthropogenic activities. Samples $S_{1}-S_{8}$ and $\mathrm{S}_{10}-\mathrm{S}_{15}$ had $\mathrm{Zn}$ origin to be from crustal source. However, $\mathrm{EF}$ value of $\mathrm{Zn}$ in $\mathrm{S}_{9}(>1.5)$ indicates possible anthropogenic source.

The $I_{\text {geo }}$ evaluated for assessed HMs (as listed in Table 10) indicated that $I_{\text {geo }}$ for manganese, cadmium, and lead in $\mathrm{S}_{1}-\mathrm{S}_{15}$ were found to be in the range of $I_{\text {geo }}>0$, suggesting "practically unpolluted" class. However, the $I_{\text {geo }}$ for $\mathrm{Fe}$ in samples $S_{1}-S_{2}$ and $S_{11}-S_{12}$ were found to be in the range $\left(0^{<} I_{\text {geo }} \leq 1\right)$, an indication of slight impact of $\mathrm{Fe}$ in the contamination of water. The $I_{\text {geo }}$ values of $\mathrm{Fe}$ in $\mathrm{S}_{13}$ and $\mathrm{S}_{15}$ lie in the range $\left(1<I_{\text {geo }}<2\right)$, which can be categorized in moderately contaminated status. Table 10 further shows that the $I_{\text {geo }}$ values of $Z n$ contents in $S_{1}-S_{2}, S_{11}-S_{13}$ and $S_{15}$ indicate "slightly polluted" state, while there is unpolluted state of $\mathrm{Zn}$ in $\mathrm{S}_{3}-\mathrm{S}_{10}$ and $\mathrm{S}_{14}$.

Table 11 lists the results of DoC, $\mathrm{mDoC}, \mathrm{ERI}$, and ERIP. The DoC for the sampled groundwater ranged from 2.36 to 10.23 (Table 11). The lowest and highest values of DoC were discovered in $\mathrm{S}_{5}$ and $\mathrm{S}_{15}$, respectively. According to Edet and Offiong (2002) classification of DoC, all the groundwater samples except $S_{5}$ and $S_{6}$ fall within high contamination class. However, it was revealed that $S_{3}-S_{10}$ as well as $S_{14}$ lie
Fig. 3 Component loading scatter plot

\section{Component Loadings}

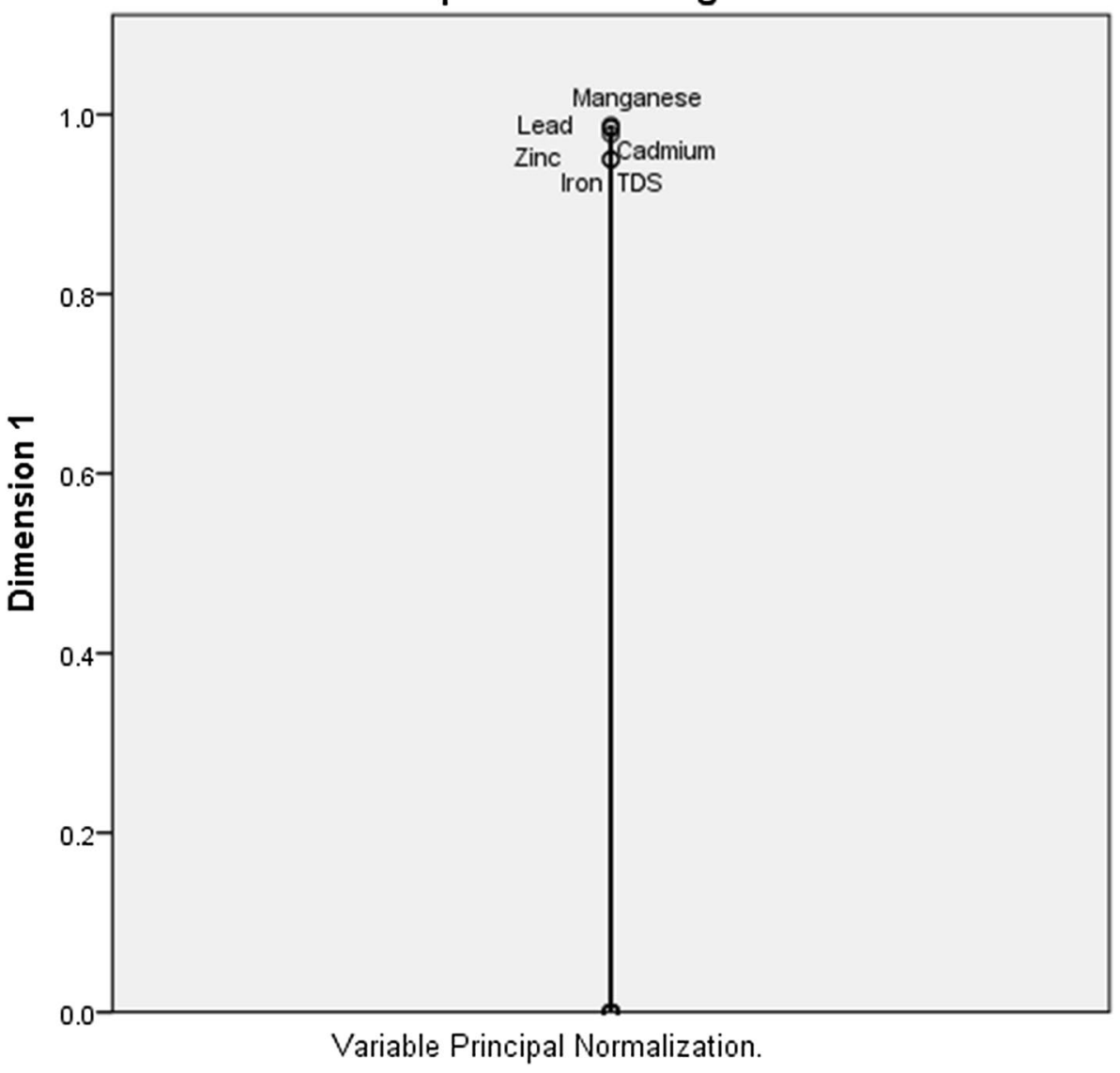


Fig. 4 Biplots of the elements

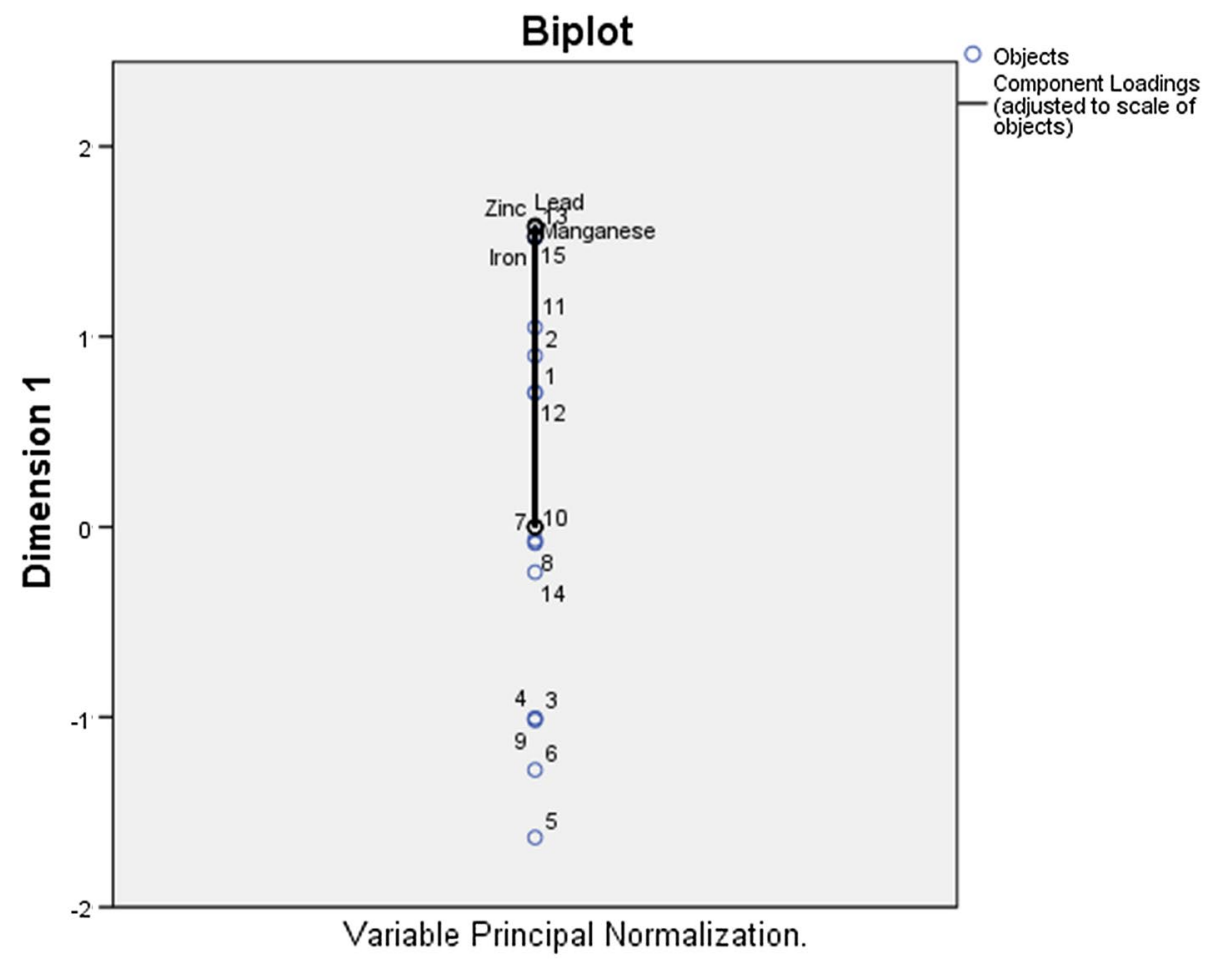

in low contamination status (DoC $<7$ ), while $S_{1}-S_{2}, S_{11}-S_{13}$ and $\mathrm{S}_{15}$ reflect significant extent of contamination according to Hakanson (1980) and Odukoya (2015) classification. The $\mathrm{mDoC}$ ranged from 0.47 to 2.05 as listed in Table 11 . The $\mathrm{mDoC}$ results in $\mathrm{S}_{3}-\mathrm{S}_{10}, \mathrm{~S}_{9}, \mathrm{~S}_{12}$ and $\mathrm{S}_{14}$ were $<1.5$, an indication of unpolluted class, while $\mathrm{mDoC}$ values in $\mathrm{S}_{1}-\mathrm{S}_{2}$, $\mathrm{S}_{11}, \mathrm{~S}_{13}$ indicate their slightly polluted state (Brady et al. 2015; Gargouri et al. 2018). The $\mathrm{mDoC}$ value (2.05) in $\mathrm{S}_{15}$ denotes its moderately polluted state.

\section{Ecological risk assessment for groundwater samples}

The ecological risk values for $\mathrm{Pb}$ in the groundwater samples varied from 3.40 to 6.50 , suggesting "mild ecological risk." In particular, the ERI results for lead in $\mathrm{S}_{3}-\mathrm{S}_{6}$ and $\mathrm{S}_{9}$ revealed low risk, while mild ecological risk of $\mathrm{Pb}$ exists in $S_{1}-S_{2}, S_{7}-S_{8}$ and $S_{10}-S_{15}$. The ERI values for cadmium in all the collected groundwater samples varied from 20.4 to 39.3; this revealed "high ecological risk" of Cd in sampled groundwater. For elements Mn, Fe and Zn, their ERI values indicated that the three metals demonstrated low ecological risk in groundwater samples from the three residential locations. The ERIP values ranged from 25.17 to 52.14 and lie in the range "low-to-moderate potential risk." For instance, samples $\mathrm{S}_{1}-\mathrm{S}_{5}$ in TCA had their ERIP values ranging from 25.17 to 47.67 an indication of being within "low-to-moderate ecological potential risk." The same goes for samples $\mathrm{S}_{6}-\mathrm{S}_{10}$ in PUA that had ERIP values ranging from 25.25 to
38.86. However, water samples in UA $\left(S_{11}-S_{15}\right)$ lie within "moderate potential ecological risk" class.

The analysis of QoC values (Table 12) showed that the concentrations of $\mathrm{Pb}, \mathrm{Cd}$, and $\mathrm{Mn}$ for the samples $\mathrm{S}_{1}-\mathrm{S}_{2}$, $\mathrm{S}_{7}-\mathrm{S}_{8}$ and $\mathrm{S}_{10}-\mathrm{S}_{15}$ were mainly derived from anthropogenic inputs, while the trio metals ( $\mathrm{Pb}, \mathrm{Cd}$, and $\mathrm{Mn}$ ) show geogenic sources in samples $S_{3}-S_{6}$ and $S_{9}$. The values of $\mathrm{Fe}$ also varied between the geogenic and anthropogenic sources. For instance, Fe concentrations in $S_{1}-S_{2}, S_{7}-S_{8}$ and $S_{11}-S_{15}$ showed anthropogenic source of contamination but of geogenic origin in $\mathrm{S}_{3}-\mathrm{S}_{6}$ and $\mathrm{S}_{9}-\mathrm{S}_{10}$. The positive QoC values of $\mathrm{Zn}$ exceeded the geogenic sources in the samples $\mathrm{S}_{1}-\mathrm{S}_{2}$, $\mathrm{S}_{7}-\mathrm{S}_{8}, \mathrm{~S}_{10}-\mathrm{S}_{13}$ and $\mathrm{S}_{15}$. However, the $\mathrm{Zn}$ concentrations in $\mathrm{S}_{3}-\mathrm{S}_{6}, \mathrm{~S}_{9}$ and $\mathrm{S}_{14}$ were shown to be associated with geogenic sources. There is disparity in identification of sources of analyzed metals in collected water samples by EF and QoC in this study. This may be due to the difference in the magnitude of input for each metal in the sample and /or the differences in the removal rate of each metal from the water samples (Zarei et al. 2014).

\section{Health risk assessment for groundwater samples}

Table 13 shows the results of non-carcinogenic health risks and probability of cancer risks for adult, child, and infant as a result of ingesting heavy metals in groundwater samples. The hazardous quotient (HQ) results for heavy metals (Fe, $\mathrm{Mn}$, and $\mathrm{Zn})$ were less than one $(\mathrm{HQ}<1)$ for adult, child, and infant, suggesting that those metals pose no apparent

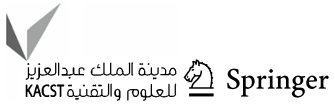


Fig. 5 A dendrogram classifying the water samples based on $\mathbf{a}$ analyzed parameters and $\mathbf{b}$ sampling points
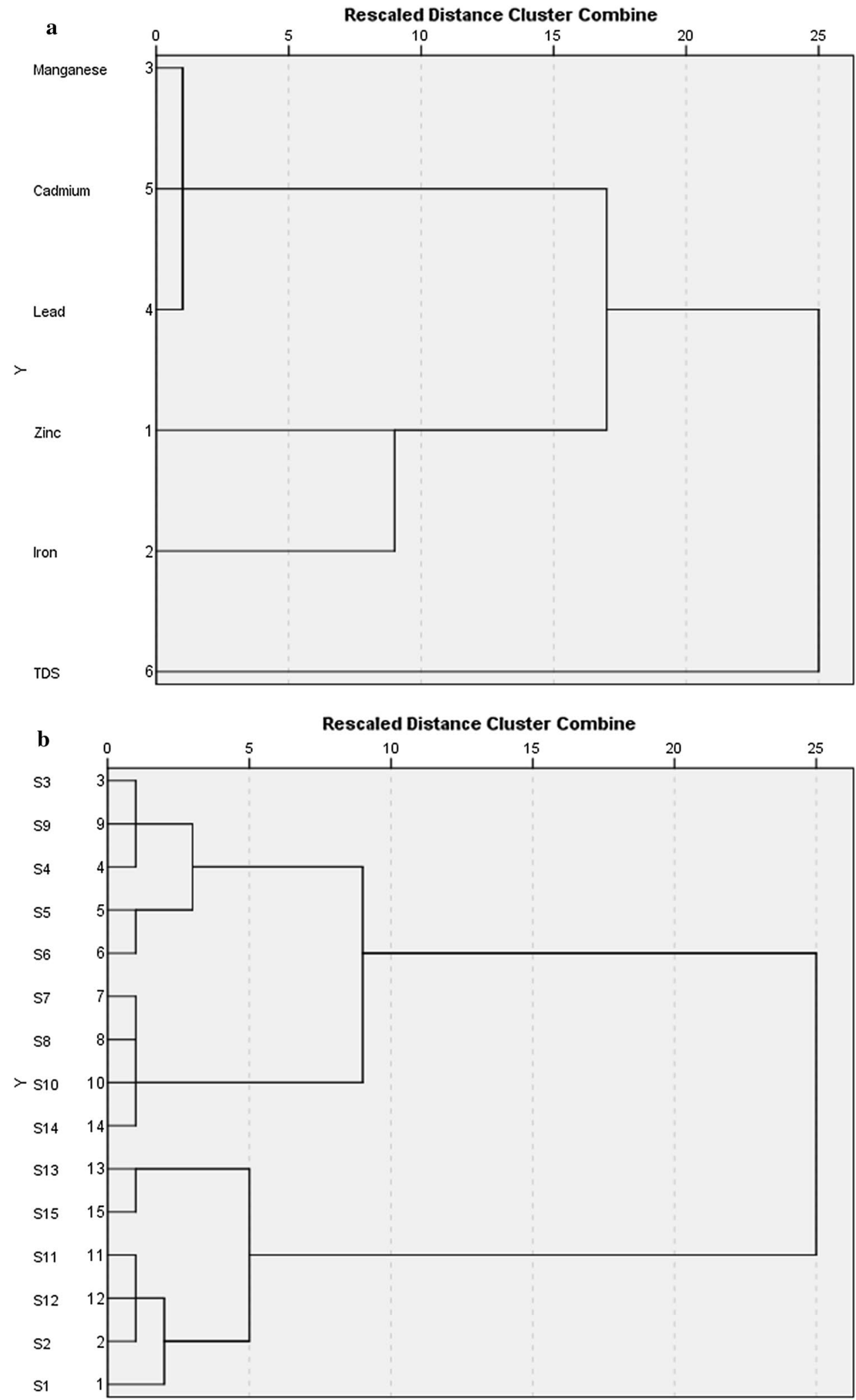

health risks. However, the HQ values (Table 13) for $\mathrm{Cd}$ and $\mathrm{Pb}$ were greater than unity, implying that these two metals pose a significant health risk. The computed HIs for adult, child, and infant were 4.65E+01, 2.33E+01, and 1.75E+01, respectively. The result of $\mathrm{HI}$ for adult $(4.65 \mathrm{E}+01)$ revealed that adults' population were more susceptible to non-carcinogenic health risk in the three residential sites. 
Table 10 Geoaccumulation index, contamination factor, enrichment factor, and pollution load index of heavy metals in groundwater samples of Ibadan metropolis

\begin{tabular}{|c|c|c|c|c|c|c|c|c|c|c|c|c|c|c|c|}
\hline \multirow[t]{2}{*}{ Sample code } & \multicolumn{5}{|l|}{$I_{\mathrm{geo}}$} & \multicolumn{5}{|l|}{$\mathrm{CF}$} & \multicolumn{4}{|l|}{$\mathrm{EF}$} & \multirow[t]{2}{*}{ PLI } \\
\hline & $\mathrm{Pb}$ & $\mathrm{Cd}$ & $\mathrm{Mn}$ & $\mathrm{Fe}$ & $\mathrm{Zn}$ & $\mathrm{Pb}$ & $\mathrm{Cd}$ & $\mathrm{Mn}$ & $\mathrm{Fe}$ & $\mathrm{Zn}$ & $\mathrm{Pb}$ & $\mathrm{Cd}$ & $\mathrm{Mn}$ & $\mathrm{Zn}$ & \\
\hline $\mathrm{S}_{1}$ & -0.35 & -0.34 & -0.34 & 0.96 & 0.34 & 1.18 & 1.19 & 1.19 & 2.92 & 1.90 & 0.40 & 0.41 & 0.41 & 0.65 & 1.32 \\
\hline $\mathrm{S}_{2}$ & -0.35 & -0.34 & -0.34 & 0.99 & 0.35 & 1.18 & 1.19 & 1.19 & 2.97 & 1.91 & 0.40 & 0.40 & 0.40 & 0.64 & 1.32 \\
\hline $\mathrm{S}_{3}$ & -0.81 & -0.82 & -0.82 & -1.73 & -1.47 & 0.85 & 0.85 & 0.85 & 0.45 & 0.54 & 1.88 & 1.87 & 1.87 & 1.20 & 0.79 \\
\hline $\mathrm{S}_{4}$ & -0.81 & -0.82 & -0.82 & -1.70 & -1.46 & 0.85 & 0.85 & 0.85 & 0.46 & 0.55 & 1.85 & 1.83 & 1.83 & 1.18 & 0.79 \\
\hline $\mathrm{S}_{5}$ & -1.14 & -1.15 & -1.15 & -3.37 & -3.09 & 0.68 & 0.68 & 0.68 & 0.14 & 0.18 & 4.71 & 4.68 & 4.68 & 1.22 & 0.55 \\
\hline $\mathrm{S}_{6}$ & -1.14 & -1.15 & -1.15 & -2.98 & -2.75 & 0.68 & 0.68 & 0.68 & 0.19 & 0.22 & 3.59 & 3.56 & 3.56 & 1.17 & 0.58 \\
\hline $\mathrm{S}_{7}$ & -0.55 & -0.56 & -0.56 & -0.46 & -0.33 & 1.02 & 1.02 & 1.02 & 1.09 & 1.19 & 0.94 & 0.94 & 0.94 & 1.09 & 1.04 \\
\hline $\mathrm{S}_{8}$ & -0.55 & -0.56 & -0.56 & -0.42 & -0.38 & 1.02 & 1.02 & 1.02 & 1.12 & 1.16 & 0.91 & 0.91 & 0.91 & 1.03 & 1.04 \\
\hline $\mathrm{S}_{9}$ & -0.84 & -0.83 & -0.84 & -2.33 & -1.52 & 0.84 & 0.84 & 0.84 & 0.30 & 0.52 & 2.80 & 2.81 & 2.81 & 1.75 & 0.74 \\
\hline $\mathrm{S}_{10}$ & -0.55 & -0.55 & -0.55 & -0.86 & -0.31 & 1.02 & 1.03 & 1.03 & 0.82 & 1.21 & 1.24 & 1.25 & 1.25 & 1.46 & 1.01 \\
\hline$S_{11}$ & -0.33 & -0.33 & -0.32 & 0.63 & 0.45 & 1.19 & 1.20 & 1.20 & 2.33 & 2.05 & 0.51 & 0.51 & 0.51 & 0.88 & 1.30 \\
\hline$S_{12}$ & -0.35 & -0.35 & -0.35 & 0.45 & 0.29 & 1.18 & 1.18 & 1.18 & 2.05 & 1.84 & 0.58 & 0.58 & 0.58 & 0.90 & 1.25 \\
\hline $\mathrm{S}_{13}$ & -0.27 & -0.27 & -0.27 & 1.25 & 0.84 & 1.24 & 1.24 & 1.25 & 3.57 & 2.68 & 0.35 & 0.35 & 0.35 & 0.75 & 1.44 \\
\hline $\mathrm{S}_{14}$ & -0.53 & -0.52 & -0.52 & -0.45 & -0.62 & 1.04 & 1.04 & 1.04 & 1.10 & 0.97 & 0.95 & 0.95 & 0.95 & 0.89 & 1.02 \\
\hline $\mathrm{S}_{15}$ & -0.20 & -0.19 & -0.20 & 1.25 & 0.88 & 1.30 & 1.31 & 1.31 & 3.56 & 2.75 & 0.37 & 0.37 & 0.37 & 0.77 & 1.47 \\
\hline
\end{tabular}

Table 11 Pollution indices, ecological risk index (ERI), and ecological risk index potential (ERIP) in groundwater samples of Ibadan metropolis

\begin{tabular}{|c|c|c|c|c|c|c|c|c|}
\hline \multirow[t]{2}{*}{ Sample code } & \multirow[t]{2}{*}{ DoC } & \multirow[t]{2}{*}{$\mathrm{mDoC}$} & \multirow[t]{2}{*}{ ER1P } & \multicolumn{5}{|l|}{ ERI } \\
\hline & & & & $\mathrm{Pb}$ & $\mathrm{Cd}$ & Mn & $\mathrm{Zn}$ & $\mathrm{Fe}$ \\
\hline $\mathrm{S}_{1}$ & 8.38 & 1.68 & 47.61 & 5.90 & 35.70 & 1.19 & 1.90 & 2.92 \\
\hline $\mathrm{S}_{2}$ & 8.44 & 1.69 & 47.67 & 5.90 & 35.70 & 1.19 & 1.91 & 2.97 \\
\hline $\mathrm{S}_{3}$ & 3.54 & 0.71 & 31.84 & 4.25 & 25.50 & 0.85 & 0.79 & 0.45 \\
\hline $\mathrm{S}_{4}$ & 3.56 & 0.71 & 31.83 & 4.25 & 25.50 & 0.85 & 0.79 & 0.46 \\
\hline $\mathrm{S}_{5}$ & 2.36 & 0.47 & 25.17 & 3.40 & 20.40 & 0.68 & 0.55 & 0.14 \\
\hline $\mathrm{S}_{6}$ & 2.45 & 0.49 & 25.25 & 3.40 & 20.40 & 0.68 & 0.58 & 0.19 \\
\hline$S_{7}$ & 5.34 & 1.07 & 38.85 & 5.10 & 30.60 & 1.02 & 1.04 & 1.09 \\
\hline $\mathrm{S}_{8}$ & 5.34 & 1.07 & 38.88 & 5.10 & 30.60 & 1.02 & 1.04 & 1.12 \\
\hline $\mathrm{S}_{9}$ & 3.34 & 0.67 & 31.28 & 4.20 & 25.20 & 0.84 & 0.74 & 0.30 \\
\hline$S_{10}$ & 5.11 & 1.02 & 38.86 & 5.10 & 30.90 & $1 . .03$ & 1.01 & 0.82 \\
\hline $\mathrm{S}_{11}$ & 7.97 & 1.59 & 46.78 & 5.95 & 36.00 & 1.20 & 1.30 & 2.33 \\
\hline $\mathrm{S}_{12}$ & 7.43 & 1.49 & 45.78 & 5.90 & 35.40 & 1.18 & 1.25 & 2.05 \\
\hline $\mathrm{S}_{13}$ & 9.98 & 1.99 & 49.66 & 6.20 & 37.20 & 1.25 & 1.44 & 3.57 \\
\hline $\mathrm{S}_{14}$ & 5.19 & 1.04 & 39.56 & 5.20 & 31.20 & 1.04 & 1.02 & 1.10 \\
\hline $\mathrm{S}_{15}$ & 10.23 & 2.05 & 52.14 & 6.50 & 39.30 & 1.31 & 1.47 & 3.56 \\
\hline
\end{tabular}

Table 13 lists the contribution of the assessed metals to the computation of HIs for the populace in the investigated residential sites. From Table 13, it was noticed that $\mathrm{Cd}$ and $\mathrm{Pb}$ have highest input to $\mathrm{HI}$ when compared to other assessed metals. It is worth noting that $\mathrm{Cd}$ played a significant role in the study area's non-carcinogenic risk assessment (see Table 13). The HI contribution of the analyzed HMs reduced in the order: $\mathrm{Cd}>\mathrm{Pb}>\mathrm{Zn}>\mathrm{Fe}>\mathrm{Mn}$.

\section{Carcinogenic health risk assessment}

As presented in Table 13, out of the 5 studied HMs in this present work, only $\mathrm{Pb}$ and $\mathrm{Cd}$ made considerable input into the evaluation of cancer risk. The probability of CR results for adult, child, and infant as a result of exposure to $\mathrm{Cd}$ was $5.00 \mathrm{E}-01 ; 2.50 \mathrm{E}-01$, and $1.87 \mathrm{E}-01$, respectively. Table 13 further shows that $\mathrm{CR}$ values due to $\mathrm{Pb}$ in drinking water for adult, child, and infant were 3.72E-04; 1.86E-04; and $1.40 \mathrm{E}-04$, respectively. This clearly reveals that $\mathrm{Cd}$ contamination had more input to the evaluation of $\mathrm{CR}$ than $\mathrm{Pb}$ for 
Table 12 Quantification of contamination (QoC) values of HMs in the water samples of Ibadan metropolis

\begin{tabular}{lrrrrr}
\hline Sample code & \multicolumn{1}{l}{$\mathrm{Pb}$} & \multicolumn{2}{l}{$\mathrm{Mn}$} & $\mathrm{Fe}$ & \multicolumn{2}{l}{$\mathrm{Zn}$} \\
\hline $\mathrm{S}_{1}$ & 15.16 & 15.270 & 15.63 & 65.72 & 47.37 \\
$\mathrm{~S}_{2}$ & 15.16 & 15.270 & 15.63 & 66.35 & 47.64 \\
$\mathrm{~S}_{3}$ & -17.23 & -18.02 & -18.19 & -120.76 & -84.06 \\
$\mathrm{~S}_{4}$ & -17.23 & -18.02 & -18.19 & -116.44 & -82.94 \\
$\mathrm{~S}_{5}$ & -46.54 & -47.52 & -47.44 & -589.89 & -466.07 \\
$\mathrm{~S}_{6}$ & -46.54 & -47.52 & -47.44 & -425.63 & -347.79 \\
$\mathrm{~S}_{7}$ & 2.31 & 2.05 & 2.03 & 8.01 & 15.96 \\
$\mathrm{~S}_{8}$ & 2.31 & 1.85 & 2.03 & 10.98 & 13.54 \\
$\mathrm{~S}_{9}$ & -19.40 & -18.88 & -19.13 & -234.49 & -91.09 \\
$\mathrm{~S}_{10}$ & 2.31 & 2.63 & 2.67 & -21.30 & 17.12 \\
$\mathrm{~S}_{11}$ & 16.26 & 16.42 & 16.57 & 57.05 & 51.22 \\
$\mathrm{~S}_{12}$ & 15.16 & 15.12 & 15.15 & 51.16 & 45.55 \\
$\mathrm{~S}_{13}$ & 19.40 & 19.58 & 19.72 & 71.98 & 62.73 \\
$\mathrm{~S}_{14}$ & 3.77 & 4.15 & 4.23 & 8.78 & -2.75 \\
$\mathrm{~S}_{15}$ & 23.24 & 23.71 & 23.63 & 71.91 & 63.68 \\
\hline
\end{tabular}

the populace in the study area. The analyzed water samples have high $\mathrm{Cd}$ and $\mathrm{Pb}$ cancer risks for adult, child, and infant in the three residential sites. The CR values obtained for the three residential areas lie above the acceptable range of $10^{-4}$ to $10^{-6}$ (Rahman et al. 2018; USEPA 2011; USEPA 2012).

\section{Conclusions}

This study was conducted in three different residential areas within Ibadan metropolis to evaluate the water quality through the assessment of levels and associated risks of selected heavy metals (HMs) in groundwater samples. The HMs analyzed included $\mathrm{Pb}, \mathrm{Cd}, \mathrm{Zn}, \mathrm{Fe}$, and $\mathrm{Mn}$. The following conclusions can be drawn.

1. The values of $\mathrm{Pb}, \mathrm{Cd}, \mathrm{Fe}$, and $\mathrm{Zn}$ for all the groundwater samples were above the recommended standard in $100 \%$, $100 \%, 86.7 \%$, and $60 \%$ of water samples, respectively.
However, the levels of Mn and TDS are within the safe limits set by World Health Organization.

2. The results of CF showed that groundwater samples from all the investigated residential areas could be classified between not contaminated $(<1)$ to moderately contaminated $(1 \leq \mathrm{CF}<3)$. However, samples $\mathrm{S}_{13}$ and $\mathrm{S}_{15}$ in UA are considerably contaminated.

3. Integrated pollution indices indicated that groundwater within the three residential sites lie in the range of "unpolluted" to "slightly polluted" class. The ERI for cadmium demonstrated high ecological risk in all assessed groundwater samples, while $\mathrm{Mn}, \mathrm{Fe}$, and $\mathrm{Zn}$ demonstrated little ERI in assessed groundwater within the residential sites. However, the calculated ERIP suggests low-to-moderate ecological risk (25.17-52.14) of these metals in residential sites.

4. The results of EF and QoC of analyzed metals in water samples indicate geogenic and anthropogenic sources. The degree of contamination in groundwater showed the following trends: UA $>$ TCA $>$ PUA.

5. Principal component analysis (PCA) extracted only one component that explained $95.68 \%$ of the total variance and linked the probable sources of analyzed parameters to both geogenic and anthropogenic inputs.

6. Possibility of sampled groundwater posing non-carcinogenic health risk through the oral intake route was identified in the three residential areas with the order of trace metals impacts as $\mathrm{Cd}>\mathrm{Pb}>\mathrm{Zn}>\mathrm{Fe}>\mathrm{Mn}$. The obtained $\mathrm{HQ}$ results are $>1$ for $\mathrm{Pb}$ and $\mathrm{Cd}$ in adult, child, and infant, representing a possible health risk. The CR values of $\mathrm{Cd}$ and $\mathrm{Pb}$ contamination were higher than the acceptable range of $\leq 1 \times 10^{-6}$ to $1 \times 10^{-4}$. Cadmium impacted more to the evaluation of CR than lead for the three categories of peoples in the studied residential locations.

7. The study recommends awareness programs toward protecting the shallow wells (especially in UA), improved hygienic practices, and pre-treatment of contaminated water before use.

Table 13 Calculated chronic daily intake (CDI), hazardous quotient (HQ), hazard index (HI), and cancer risk (CR) for studied heavy metals in water samples

\begin{tabular}{|c|c|c|c|c|c|c|c|c|c|}
\hline \multirow[t]{2}{*}{ Parameters } & \multicolumn{3}{|l|}{ CDI } & \multicolumn{3}{|l|}{ HQ } & \multicolumn{3}{|l|}{ CR } \\
\hline & Adult & Child & Infant & Adult & Child & Infant & Adult & Child & Infant \\
\hline $\mathrm{Pb}$ & $4.38 \mathrm{E}-02$ & $2.19 \mathrm{E}-02$ & $1.64 \mathrm{E}-02$ & $1.22 \mathrm{E}+01$ & $6.09 \mathrm{E}+00$ & $4.56 \mathrm{E}+00$ & $3.72 \mathrm{E}-04$ & $1.86 \mathrm{E}-04$ & $1.40 \mathrm{E}-04$ \\
\hline $\mathrm{Cd}$ & $3.33 \mathrm{E}-02$ & $1.67 \mathrm{E}-02$ & $1.25 \mathrm{E}-02$ & $3.33 \mathrm{E}+01$ & $1.67 \mathrm{E}+01$ & $1.25 \mathrm{E}+01$ & $5.00 \mathrm{E}-01$ & $2.50 \mathrm{E}-01$ & $1.87 \mathrm{E}-01$ \\
\hline $\mathrm{Mn}$ & $2.03 \mathrm{E}-03$ & $1.01 \mathrm{E}-03$ & $7.60 \mathrm{E}-04$ & $1.45 \mathrm{E}-02$ & $7.23 \mathrm{E}-03$ & $5.43 \mathrm{E}-03$ & & & \\
\hline $\mathrm{Fe}$ & $1.13 \mathrm{E}-01$ & $5.66 \mathrm{E}-02$ & $4.25 \mathrm{E}-02$ & $1.62 \mathrm{E}-01$ & $8.09 \mathrm{E}-02$ & $6.06 \mathrm{E}-02$ & & & \\
\hline $\mathrm{Zn}$ & $2.62 \mathrm{E}-01$ & $1.31 \mathrm{E}-01$ & $9.84 \mathrm{E}-02$ & $8.74 \mathrm{E}-01$ & $4.37 \mathrm{E}-01$ & $3.28 \mathrm{E}-01$ & & & \\
\hline HI & & & & $4.65 \mathrm{E}+01$ & $2.33 E+01$ & $1.75 \mathrm{E}+01$ & & & \\
\hline
\end{tabular}


Authors' contribution All authors contribute to the study conception and design. Material preparation, data collection, as well as analyses were performed by Saheed Adekunle Ganiyu, Abimbola Oyadeyi, and Azeem Adeyemi.

Funding No fund was received for conducting this study.

\section{Declaration}

Conflict of interest The authors declare that they have no conflicts of interest.

Open Access This article is licensed under a Creative Commons Attribution 4.0 International License, which permits use, sharing, adaptation, distribution and reproduction in any medium or format, as long as you give appropriate credit to the original author(s) and the source, provide a link to the Creative Commons licence, and indicate if changes were made. The images or other third party material in this article are included in the article's Creative Commons licence, unless indicated otherwise in a credit line to the material. If material is not included in the article's Creative Commons licence and your intended use is not permitted by statutory regulation or exceeds the permitted use, you will need to obtain permission directly from the copyright holder. To view a copy of this licence, visit http://creativecommons.org/licenses/by/4.0/.

\section{References}

Abrahim GMS, Parker RJ (2008) Assessment of heavy metal enrichment factors and degree of contamination in marine sediments from Tamaki Estuary, Auckland, New Zealand. Estuar Coast Shelf Sci 136:227-238

Adelekan IO (2016) Ibadan city diagnostic report working paper no. 4 urban Africa risk knowledge

Adelekan I, Olajide-Taiwo L, Ayorinde A, Ajayi D, Babajide S (2014) Building urban resilience: assessing urban and peri-urban agriculture in Ibadan, Nigeria. In: Padgham J, Jabbour J (eds). United Nations Environment Programme (UNEP), Nairobi, Kenya

Adeleye AT, Olayiwola L (2016) Spatial variation in residents accessibility to land for housing development in Ibadan metropolis, Oyo State, Nigeria. Ethiop J Environ Stud Manag 9(2):1047-1058. https://doi.org/10.4314/ejesm.v9i210S

Adhikari K, Mal U (2019) Application of multivariate statistics in the analysis of groundwater geochemistry in and around the open cast coal mines of Barjora block, Bankura district, West Bengal, India. Environ Earth Sci 78:72. https://doi.org/10.1007/ s12665-019-8071-0

Afrifa CG, Ofosu FG, Bamford SA, Wordson DA, Atiemo SM, Aboh IJ, Adeti JP (2013) Heavy metal contamination in surface soil dust at selected fuel filling stations in Accra, Ghana. Am J Sci Ind Res 4:404-413

Aigberua AO, Ogbuta AA, Izah SC (2020) Selected heavy metals in sediment of Taylor creek due to anthropogenic activities in the Niger Delta region of Nigeria: geochemical spreading and evaluation of environmental risk. Biodivers Int J 4(2):67-80. https:// doi.org/10.15406/bij.2020.04.00166

Akanbi OA (2018) Hydrological characterization and prospect of basement aquifers of Ibarapa region, southwestern Nigeria. Appl Water Sci 8:89. https://doi.org/10.1007/s13201-018-0731-9

Akoto O, Teku JA, Gasinu D (2019) Chemical characteristics and health hazards of heavy metals in shallow groundwater: case study Anloga community, Volta Region, Ghana. Appl Water Sci 9:36. https://doi.org/10.1007/s13201-019-0914-z

Amadi AN, Dan-Hassan MA, Okoye NO, Ejiofor IC, Tukur A (2013) Studies on pollution hazards of shallow hand-dug wells in Erena and environs, North-central Nigeria. Environ Nat Resour Res 3(2):69-77

Amfo-Otu R, Agyenim JB, Nimba-Bumah GB (2014) Correlation analysis of groundwater colouration from mountaineous area, Ghana. Environ Res Eng Manag 1(67):16-24

Areola AA, Ikporukpo CO (2018) Social ecology and urban green spaces in Ibadan, Nigeria. J Appl Sci Environ Manag 22(7):1111-1120

Arias JA, Peralta-Videa JR, Ellzey JT, Ren M et al (2010) Effects of Glomus deserticola inoculation on Prosopis: enhancing the chromium and lead uptake and translocation as confirmed by $\mathrm{X}$-ray mapping, ICP-OES and TEM techniques. Environ Exp Bot 68:139-148

Asaah VA, Abimbola AF, Suh CE (2006) Heavy metal concentrations and distribution in surface soils of the Bassa industrial zone 1, Douala Cameroon. Arab J Sci Eng 31:147-158

Ayantobo OO, Oluwasanya GO, Idowu OA, Eruola AO (2013) Water quality evaluation of Hand-dug wells in Ibadan, Oyo state, Nigeria. Glob J Sci Front Res Agric Vet 13(10):21-27

Ayedun H, Gbadebo AM, Idowu OA, Arowolo TA (2015) Toxic elements in groundwater of Lagos and Ogun States southwest Nigeria and their human health risk assessment. Environ Monit Assess 187(6):1-17

Barakat A, Baghdadi ME, Rais J, Aghezzaf B, Slassi M (2016) Assessment of spatial and seasonal water quality variation of Oum ErRbia River (Morocco) using multivariate statistical techniques. Int Soil Water Conserv Res 4(4):284-292

Barzegar R, Moghaddam AA, Kazemian N (2015) Assessment of heavy metal concentrations with emphasis on arsenic in the Tabriz plain aquifers, Iran. Environ Earth Sci 74:297-313. https://doi.org/10.1007/s12665-015-4123-2

Barzegar R, Asghari Moghaddam A, Tziritis E, Fakhri MS, Soltani S (2017) Identification of hydrogeochemical processes and pollution sources of groundwater resources in the Marand plain, northwest of Iran. Environ Earth Sci 76(7):297. https://doi.org/ 10.1007/s12665-017-6612-y

Barzegar R, Moghaddam AA, Soltani S, Baomid N, Tziriti SE, Adamowski J, Inam A (2019) Natural and anthropogenic origins of selected trace elements in the surface water of Tabriz area, Iran. Environ Earth Sci 78:254. https://doi.org/10.1007/ s12665-019-8250-z

Bhutiani R, Kulkarni DB, Khanna DR, Gautam A (2017) Geochemical distribution and environmental risk assessment of heavy metals in groundwater of an industrial areas and its surroundings, Haridwar, India. Energy Ecol Environ 2:155-167. https://doi.org/10. 1007/s40974-016-0019-6

Bilgin A, Konane MU (2016) Evaluation of surface water quality and heavy metal pollution of Coruh River basin (Turkey) by multivariate statistical methods. Environ Earth Sci 75:1029. https:// doi.org/10.1007/s12665-016-5821-0

Bolarinwa AT (2017) Hydro geochemistry of groundwater within the lateritic profiles over migmatite and pegmatised schist of Ibadan, Nigeria. J Geol Min Res 9(4):28-42. https://doi.org/10.5897/ JGMR2016.0261

Brady JP, Ayoko GA, Martens WN, Goonetilleke A (2015) Development of a hybrid pollution index for heavy metals in marine and estuarine sediments. Environ Monit Assess 187:1-14

Cao SZ, Duan XL, Zhao X, Wang B, Ma J, Fan D et al (2015) Health risk assessment of various metal (loids) via multiple exposure pathways on children living near a typical lead-acid battery plant, China. Environ Pollut 200:16-23 
Chen J, Wu H, Qian H, Gao Y (2017) Assessing nitrate and fluoride contaminants in drinking water and their health risk of rural residents livings in a semiarid region of Northwest China. Expo Health 9(3):183-195

Clark L (1985) Groundwater abstraction from Basement Complex areas of Africa. Q J Eng GeolHydrogeol 18(1):25-34

Deely JM, Fergusson JE (1994) Heavy metal and organic matter concentrations and distributions in dated sediments of a small estuary adjacent to a small urban area. Sci Total Environ 153:97-111

Devanesan E, Gandhi MS, Selvapandiyan M, Senthilkumar G, Ravisankar R (2017) Heavy metal and potential ecological risk assessment in sediments collected from Poombuharto Karaikal coast of Tamilnadu using Energy dispersive X-ray fluorescence (EDXRF) technique. Beni-Suef Univ J Basic Appl Sci 6:285-292

Duggal V, Rani A, Mehra R, Balaram V (2017) Risk assessment of metals from groundwater in northeast Rajasthan. J Geol Soc India 90(1):77-84

Edet AE, Offiong OE (2002) Evaluation of water quality pollution indices for heavy metal contamination monitoring. A study case from Akpabuyo-Odukpani area, lower Cross River Basin (Southeastern Nigeria). Geo J 57:295-304

Egboka BCE, Mbanugoh RE, Nwogute NS, Uma KO, Okpoko EI (1988) Positive implications of Hand-dug wells in water resources planning and management in a developing economy such as Nigeria. Water Int 13:98-105

Egbueri JC (2019) Water quality appraisal of selected farm provinces using integrated hydrogeochemical multivariate, statistical and microbiological technique. Model Earth Syst Environ. https:// doi.org/10.1007/s40808-019-00585-Z

Egbueri JC (2020) Heavy metals pollutiom source identification and probabilistic health risk assessment of shallow groundwater in Onitsha, Nigeria. Anal Lett. https://doi.org/10.1080/00032 719.2020 .1712606

Egbueri JC, Mgbenu CN (2020) Chemometric analysis of pollution source identification and human health risk assessment of water resources in Ojoto Province, southeast Nigeria. Appl Water Sci 10:98. https://doi.org/10.1007/s13201-020-01180-9

Egbueri JC, Ameh PD, Ezugwu CK, Onwuka OS (2020) Evaluating the environmental risk and suitability of hand-dug wells for drinking purposes: a rural case study from Nigeria. Int $\mathbf{J}$ Environ Anal Chem. https://doi.org/10.1080/03067319.2020. 1800000

Enuneku A, Omoruyi O, Tongo I, Ogbomida E, Ogbeide O, Ezemonye L (2018) Evaluating the potential health risks of heavy metal pollution in sediment and selected benthic fauna of Benin River, Southern Nigeria. Appl Water Sci 8:224. https://doi.org/10.1007/ s13201-018-0873-9

Ganiyu SA, Olurin OT, Awaye KT, Adeleke OO (2017) Heavy metals content and physico-chemical status of groundwater around lead smelting area in southwestern Nigeria Urban settlement. Afr Rev Phys 12:14-22

Ganiyu SA, Badmus BS, Olurin OT, Ojekunle ZO (2018) Evaluation of seasonal variation of water quality using multivariate statistical analysis and irrigation parameter indices in Ajakanga area, Ibadan, Nigeria. Appl Water Sci 8:35. https://doi.org/10.1007/ s13201-018-0677-y

Gaonkar CV, Matta VM (2019) Impact of mining on metal concentration in waters of the Zuari estuary, India. Environ Monit Assess 191:368. https://doi.org/10.1007/s10661-019-7506-0

Gargouri D, Gzam M, Kharroubi A, Jedoui Y (2018) Use of sediment quality indicators for heavy metals contamination and ecological risk assessment in urbanized coastal zones. Environ Earth Sci 77:381. https://doi.org/10.1007/s12665-018-7567-3

Giri S, Singh AK (2019) Assessment of metal pollution in groundwater using a novel multivariate metal pollution index in the mining areas of the Singhbhum copper belt. Environ Earth Sci 78:192. https://doi.org/10.1007/s12665-019-8200-9

Google Earth vers 7.3.2.5776(beta). https://www.google.com/earth explorer.usgs.gov

Gu YG, Gao YP (2018) Bioaccessibilities and health implications of heavy metals in exposed-lawn soils from 28 urban parks in the mega city Guangzhou inferred from an in vitro physiologically based extraction test. Ecotoxicol Environ Saf 148:747-753

Hajigholizadeh M, Melesse AM (2017) Assortment and spatio temporal analysis of surface water quality using cluster and discriminant analyses. CATENA 151:247-258

Hakanson L (1980) An ecological risk index for aquatic pollution control-a sedimentological approach. Water Res 14:975-1001. https://doi.org/10.1016/0043-1354(80)90143-8

Hamid A, Bhat SA, Bhat SU, Jehangir A (2016) Environmetric techniques in water quality assessment and monitoring: a case study. Environ Earth Sci 75:321. https://doi.org/10.1007/ s12665-015-5139-3

Herngren L, Goonetilleke A, Ayoko GA (2005) Understanding heavy metal and suspended solids relationships in urban stormwater using simulated rainfall. J Environ Manag 76:149-158. https:// doi.org/10.1016/j.jenvman.2005.01.013

Kaiser HF (1960) The application of electronic computers to factor analysis. Educ Psychol Meas 20(1):141-151

Kim H, Park S (2016) Hydrogeochemical characteristics of Groundwater highly polluted with nitrate in an agricultural area of Hongseong, Korea. Water 8:345. https://doi.org/10.3390/w808a0345

Kladsomboon S, Jaiyen C, Choprathumma C, Tusai T, Apilux A (2019) Heavy metals contamination in soil, surface water, crops and residents blood in Uthai District, Phra Nakhonsi Ayutthaya, Thailand. Environ Geochem Health. https://doi.org/10.1007/ s10653-019-00388.2

Kshetrimayum KS, Hegeu H (2016) The state of toxicity and cause of elevated iron and manganese concentrations in surface water and groundwater around Naga Thrust of Assam-Arakan basin, Northeastern India. Environ Earth Sci 75:604. https://doi.org/10. 1007/s12665-016-5372-4

Kumar A, Mishra S, Kumar A, Singhal S (2017) Environmental quantification of soil elements in the catchment of hydroelectric reservoirs in India. Hum Ecol Risk Assess Int J. https://doi.org/10. 1080/10807039.2017.1309266

Kumar A, Kumar A, Cabral-Pinto MMS et al (2020a) Lead toxicity: health hazards, influence on food chain, and sustainable remediation approaches. Int J Environ Res Public Health 17:2179. https:// doi.org/10.3390/ijerph17072179

Kumar A, Cabral-Pinto M, Kumar A, Kumar M, Dinis PA (2020b) Estimation of risk to the eco-environment and human health of using heavy metals in the Uttarakhand Himalaya, India. Appl Sci 10:7078. https://doi.org/10.3390/app10207078

Kumar A, Subrahmanyam G, Mondal R, Cabral-Pinto MMS, Shabnam AA et al (2020c) Bio remediation approaches for alleviation of cadmium contamination in natural resources. Chemosphere. https://doi.org/10.1016/j.chemosphere.2020.128855

Kumar A, Ali M, Kumar R, Kumar M et al (2021) Arsenic exposure in Indo Gangetic plains of Bihar causing increased cancer risk. Sci Rep 11:2376. https://doi.org/10.1038/s41598-021-81579-9

Ling C, Zhang Q (2017) Evaluation of surface water and groundwater contamination in a MSW landfill area using hydrochemical analysis and electrical resistivity tomography: a case study in Sichuan province, Southwest China. Environ Monit Assess 189:140. https://doi.org/10.1007/S1066I-017-5832-7

Liu J, Zhang D, Tang Q, Xu H, Huang S, Shang D et al (2021) Water quality assessment and source identification of the Shuangji River (China) using multivariate statistical methods. PLoS ONE 16(1):e0245525. https://doi.org/10.1371/journal.pone.0245525 
Lloyd PC, Mabogunje AL (eds) (1968) The city of Ibadan. Cambridge University Press, London. https://doi.org/10.1525/aa.1968.70.5. 02a00290

Lutterodt G, Vossenberg J, Hoiting Y, Kamara AK, Oduro-Kwarteng S, Foppen JWA (2018) Microbial groundwater quality status of hand-dug wells and boreholes in the Dodowa Area of Ghana. Int J Environ Res Public Health 15:730. https://doi.org/10.3390/ ijerph 15040730

Mazhar I, Hamid A, Afzal S (2019) Groundwater quality assessment and human health risks in Gujranwala District, Pakistan. Environ Earth Sci 78:634. https://doi.org/10.1007/s12665-019-8644-y

Mbaka PK, Mwangi JK, Kiptum CK (2017) Assessment of water quality in selected shallow wells of Keiyo Highlands, Kenya. Afr J Sci Technol Innov Dev. https://doi.org/10.1080/20421338.2017. 1327476

Mgbenu CN, Egbueri JC (2019) The hydrogeochemical signatures, quality indices and health risk assessment of water resources in Umunya district, southeast Nigeria. Appl Water Sci. https://doi. org/10.1007/s13201-019-0900-5

Mirzabeygi M, Abbasnia A, Yunesian M, Nodehi RN, Yousefi N, Hadi M, Mahvi AH (2017) Heavy metal contamination and health risk assessment in drinking water of Sistan and Baluchistan, Southeastern iran. Hum Ecol Risk Assess 23:18931905. https://doi.org/10.1080/10807039.2017.1322895

Muller G (1969) Index of geoaccumulation in sediments of the Rhine river. Geol J 2:109-118

Nawab J, Khan S, Khan MA, Sher H, Rehamn UU, Ali S, Shah SM (2017) Potentially toxic metals and biological contamination in drinking water sources in Chromite mining-impacted areas of Pakistan: a comparative study. Expo Health 9:275-287

NGSA (2016) Geological and mineral resources map of Ogun State, Nigeria. Nigerian Geological Survey Agency, Abuja, Nigeria

NIS (Nigerian Industrial Standard) (2015) Nigerian standard for drinking water quality. N1S-554-2015. $28 \mathrm{p}$

Nowrouzi M, Pourkhabbaz A (2014) Application of geoaccumulation index and enrichment factor for assessing metal contamination in the sediments of Hara Biosphere Reserve, Iran. Chem Speciat Bioavailab 26(2):99-105. https://doi.org/10.3184/095422914X 13951584546986

NPC (2010) National Population Commission Nigeria, Retrieved from: http://www.population.gov.ng/

Odukoya AM (2015) Contamination assessment of toxic elements in the soil within and around two dumpsites in Lagos, Nigeria. Ife J Sci 17(2):351-361

Odukoya AM, Abimbola AT (2010) Contamination assessment of surface and groundwater within and around two dumpsites. Int $\mathbf{J}$ Environ Sci Technol 7(2):367-376

Ogundele LT, Adejooro IA, Ayeku PO (2019) Health risk assessment of heavy metals in soil from an abandoned industrial waste dumpsite in Ibadan, Nigeria. Environ Monit Assess 191:290. https://doi.org/10.1007/s10661-019-7454-8

Okunlola OA, Adeigbe OC, Oluwatoke OO (2009) Compositional and petrogenetic features of schistose rocks of Ibadan area, southwestern Nigeria. Earth Sci Res J 3(2):20-43

Olorunfemi MO, Fasuyi SA (1993) Aquifer types and the geoelectric/ hydrogeologic characteristics of part of the central basement terrain of Nigeria (Niger State). J Afr Earth Sci (Middle East) 16(3):309-317

Olujimi O, Steiner O, Goessler W (2014) Pollution indexing and health risk assessment of trace elements in indoor dust from classrooms, living rooms and offices in Ogun State, Nigeria. J Afr Earth Sci 101:396-404

Orebiyi EO, Awomeso JA, Idowu OA, Martins O, Oguntoke O, Taiwo AM (2010) Assessment of pollution hazards of shallow well water in Abeokuta and Environs. Southwest Nigeria. Am J Environ Sci 6(1):50-56
Osipova NA, Kate AF, Anna VT, Egor GY (2015) Geochemical approach to human health risk assessment of inhaled trace elements in the vicinity of industrial enterprises in Tomsk, Russia. Hum Ecol Risk Assess Int J 21(6):1664-1685

Pal DK, Agrawal A, Ghosh S, Gosh A (2020) Association of arsenic with recurrence of urinary bladder cancer. Trop Doct 0(0):1-5. https://doi.org/10.1177/004947552930155

Palmucci W, Rusi S, Di Curzio D (2016) Mobilization processes responsible for iron and manganese contamination of groundwater in Central Adriatic Italy. Environ Sci Pollut Res 23:11790-11805

Panthi J, Li F, Wang H, Aryal S, Dahal P, Ghimire S, Kabenge M (2017) Evaluating climatic and non-climatic stresses for declining surface water quality in Bagmati River of Nepal. Environ Monit Assess 189:292. https://doi.org/10.1007/s10661-017-6000-9

Paul R, Brindha K, Gowrisankar G, Tan ML, Singh MK (2019) Identification of hydrogeochemical processes controlling groundwater quality in Tripura, Northeast India using evaluation indices, GIS and multivariate statistical methods. Environ Earth Sci 78:470. https://doi.org/10.1007/s12665-019-8479-6

Popoola LT, Yusuff AS, Aderibigbe TA (2019) Assessment of natural groundwater physic-chemical properties in major industrial and residential locations of Lagos metropolis. Appl Water Sci 9:191. https://doi.org/10.1007/s13201-019-1073-y

Prasad B, Kumari P, Bano S, Kumari S (2008) Groundwater quality evaluation near a mining area and development of heavy metal pollution index. Appl Water Sci 4:59. https://doi.org/10.1007/ s13201-013-0126-x

Przydatek G, Kanownik W (2019) Impact of small municipal solid waste landfill on groundwater quality. Environ Monit Assess 191:169. https://doi.org/10.1007/s10661-019-7279-5

Rahman MM, Islam MA, Bodrud-Doza M et al (2018) Spatio-temporal assessment of groundwater quality and human health risk: a case study in Gopalganj Bangladesh. Expo Health 10:167-188. https://doi.org/10.1007/s12403-017-0253-y

Rahman MATMT, Paul M, Bhoumik N, Hassan M, Alam MK, Aktar $\mathrm{Z}$ (2020) Heavy metal pollution assessment in the groundwater of the Meghna Ghat industrial area, Bangladesh, by using water pollution indices approach. Appl Water Sci 10:186. https://doi. org/10.1007/s13201-020-01266-4

Ravindra K, Mor S (2019) Distribution and health risk assessment of arsenic and selected heavy metals in groundwater of Chandigarh, India. Environ Pollut 250:820-830

Saleem A, Dandigi MN, Vijay KK (2012) Correlation and regression model for physicochemical quality of groundwater in the south Indian city of Gulbarga. Afr J Environ Sci Technol 6(9):353-364

Selvakumar S, Chandrasekar N, Kumar G (2017) Hydrogeochemical characteristics and groundwater contamination in the rapid urban development areas of Coimbatore, India. Water Resour Ind 17:26-33

Selvam S, Anthony Ravindran A, Venkatramanan S, Singaraja C (2017) Assessment of heavy metal and bacterial pollution in coastal aquifers from SIPCOT Industrial zones, Gulf of Mannar, South coast of Tamil Nadu, India. Appl Water Sci 7:897-913. https:// doi.org/10.1007/s13201-015-0301-3

Shah MH, Ilyas A, Akhter G, Bashir A (2019) Pollution assessment and source apportionment of selected metals in rural (Bagh) and Urban (Islamabad) farmlands, Pakistan. Environ Earth Sci 78:199. https://doi.org/10.1007/s12665-019-8198-z

Shankar BS (2019) A critical assay of heavy metal pollution index for the groundwater of Peenya Industrial Area, Bangalore, India. Environ Monit Assess 191:289. https://doi.org/10.1007/ s10661-019-7453-9

Singh AL, Singh VK (2018) Assessment of groundwater quality of Ballia district, Uttar Pradesh, India with reference to arsenic

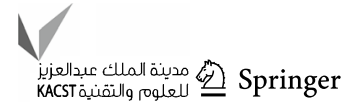


contamination using multivariate statistical analysis. Appl Water Sci 8:95. https://doi.org/10.1007/S1320/-018-0737-3

Singh AL, Singh VK (2019) Assessment of groundwater quality of Balha district, Uttar Pradesh, India with reference to arsenic contamination using multivariate statistical analysis. Appl Water Sci 8:95. https://doi.org/10.1007/s13201-018-0737-3

Singh S, Lal S, Harjit L, Amlathe S, Kataria HC (2011) Potential of metal extractions in determination of trace metals in water samples. Adv Stud Biol 3(5):239-246

Sorensen JPR, Lapworth DJ, Read DS, Nkuwa DCW, Bell RA, Chibesa M, Chirwa M, Kabika J, Liemisa M, Pedly S (2015) Tracing enteric pathogen contamination in Sub-saharan Africa groundwater. Sci Total Environ 538:888-895

Suvarapu LN, Baek SD (2017) Determination of heavy metals in the ambient atmosphere: a review. Toxicol Ind Health 33(1):79-96

Tomlinson DL, Wilson JG, Harris CR, Jeffrey DW (1980) Problems in the assessment of heavy metal levels in estuaries and the formation of a pollution index. Helgol Wiss Meeresunters 33(1-4):566-575

Tripti AK, Maleva M, Kiseleva I, Maiti SK, Morozova M (2019) Toxic metal (loid)s contamination and potential human health risk assessment in the vicinity of century-old copper smelter, Karabash, Russia. Environ Geochem Health. https://doi.org/10. 1007/s10653-019-00414-3

Ukah BU, Egbueri JC, Unigwe CO, Ubido OE (2019) Extent of heavy metals pollution and health risk assessment of groundwater in a densely populated industrial area, Lagos, Nigeria. Int J Energy Water Resour. https://doi.org/10.1007/s42108-019-00039-3

USEPA (2011) United States Environmental Protection Agency: integrated risk information system (IRIS). Environmental Protection Agency Region. Washington DC, 20460. http://www.epa.gov.iris. Accessed May 2018

USEPA (2012) Integrated risk information system, United States Environmental Protection Agency. https://cfpub.epa.gov/nceal/iris/ index.cfm?fuseaction-iris.showsubstance.list. Accessed 3 May 2012

Usman NU, Toriman ME, Juhais H, Abdullahi MG, Rabiu AA, Isiyaka $\mathrm{H}$ (2014) Assessment of groundwater quality using multivariate statistical technique in Terengganu. Sci Technol 4(3):42-49
Vetrimurugan E, Brindha K, Elango L (2017) Human exposure risk assessment due to heavy metals in groundwater by pollution index and multivariate statistical methods: a case study from South Africa. Water 9:234. https://doi.org/10.3390/w9040234

Wagh V, Panaskar D, Muley et al (2018) Neural network modelling for nitrate concentration in groundwater of Kadava River basin, Nashik, Maharashtra, India. Groundw Sustain Dev. https://doi. org/10.1016/j.gsd.2017.12.012

Wahab B, Popoola A (2018) Climate-induced problems and adaptation strategies of Urban farmers in Ibadan. Ethiop J Environ Stud Manag 11(1):31-42

WHO (2015) Section 1: managing the quality of drinking water sources. In: Schmoll O, Howard G, Chilton G (eds) Protecting groundwater for health. Managing the quality of drinking water. IWA Publishing for World Health Organization, Geneva

Wu J, Zhou H, He S, Zhang Y (2019) Comprehensive understanding of groundwater quality for domestic and agricultural purposes in terms of health risks in a coal mine area of the Ordos basin, north of the Chinese Loess plateau. Environ Earth Sci 78:446. https:// doi.org/10.1007/s12665-019-8471-1

Zarei I, Pourkhabbaz A, Khuzestani RB (2014) An assessment of metal contamination risk in sediments of Hara Biosphere Reserve, southern Iran with a focus on application of pollution indicators. Environ Monit Assess. https://doi.org/10.1007/ s10661-014-3839-x

Zhang Z, Xiao C, Adeyeye O, Yang W, Liang X (2020) Source and mobilization mechanism of Iron, manganese and Arsenic in groundwater of Shuangliao city, northeast China. Water 12:534. https://doi.org/10.3390/W12020534

Publisher's Note Springer Nature remains neutral with regard to jurisdictional claims in published maps and institutional affiliations. 